\title{
The Topography of the Chlorophyll Apparatus in Desert Plants.
}

BY

WILLIAM AUSTIN CANNON.

The Induction, Development, and Heritability of Fasciations.

BY

ALICE ADELAIDE KNOX.

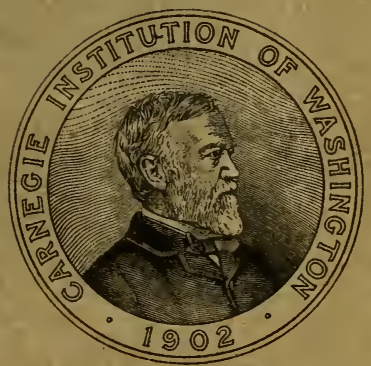

WASHINGTON, D. C.

Published by the Carnegie Institution of Washington.

QK882

1908. C3 


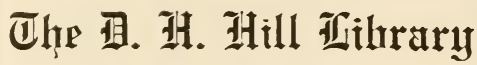

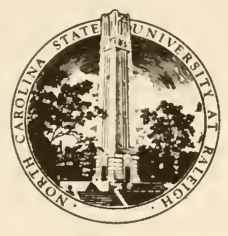

Sirth Caralina \$tate Alniueruity 15

a State Library

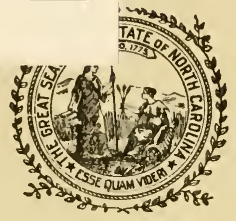

Gift of 


\section{The Topography of the Chlorophyll Apparatus in Desert Plants.}

WILLIAM AUSTIN CANNON.

\section{The Induction, Development, and Heritability of Fasciations.}

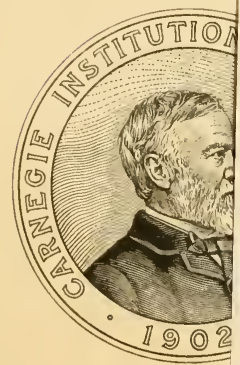

THIS BOOK IS DUE ON THE DATE INDICATED BELOW AND IS SUBJECT TO AN OVERDUE FINE AS POSTED AT THE CIRCULATION DESK. 


\section{CARNEGIE INSTITUTION OF WASHINGTON}

Publication No. 98

THE CORNMAN PRINTING CO.,

CARLISLE, PA. 


\section{The Topography of the Chlorophyll Apparatus in Desert Plants.}

$$
\text { BY }
$$

WILLIAM AUSTIN CANNON. 



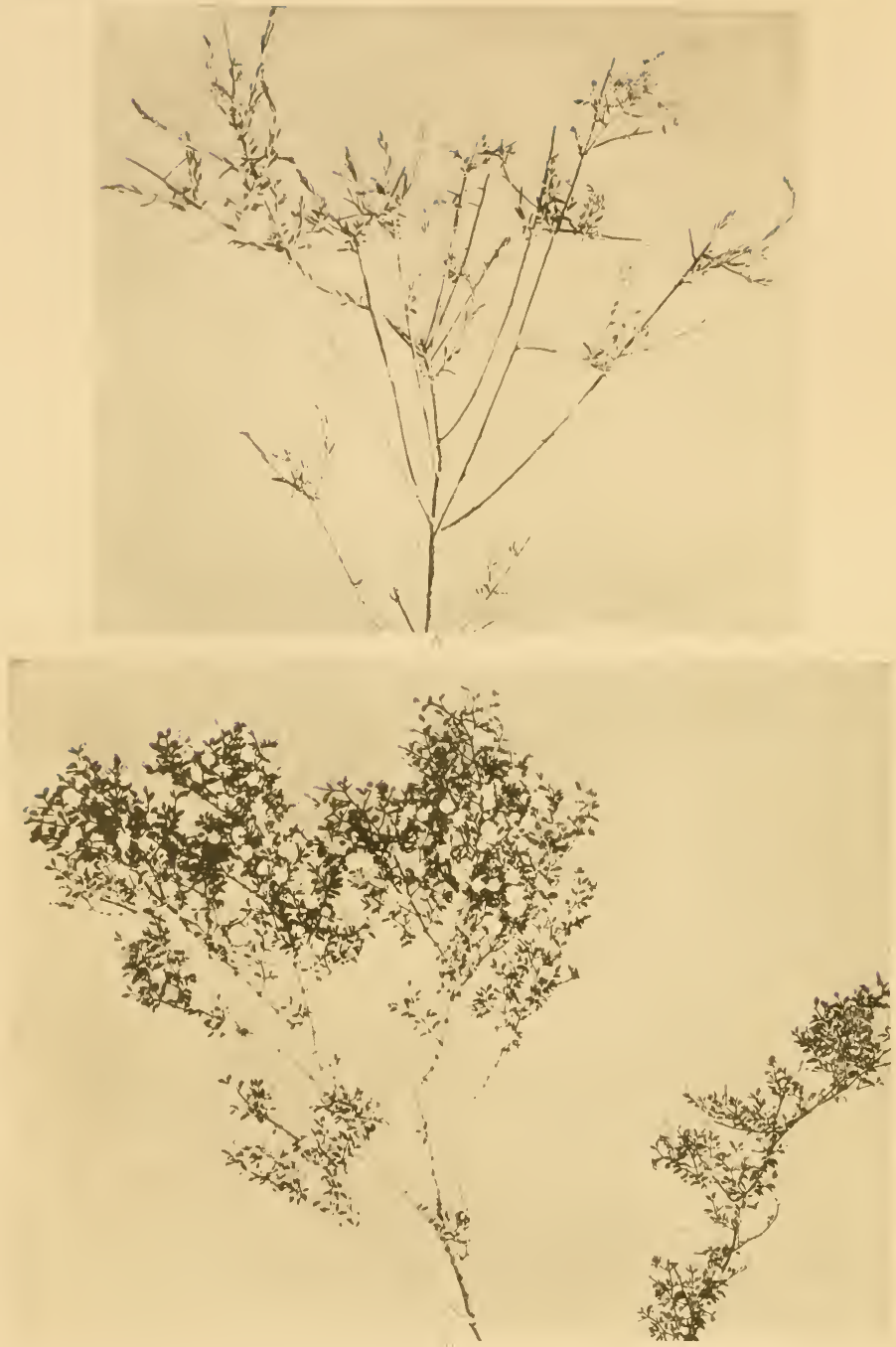

A - KRAMERIA CANESCENS. Branch from a plant which is growing on the slope at the northern base of the Tumamoc Hill. This is a plant with the deciduous habit. April 25, 1907.

B.-COVILLEA TRIDENTATA. Branch in fruit of a plant which is growing near the laboratory building. This is an evergreen. April 25, 1907. 


\section{THE TOPOGRAPHY OF THE CHLOROPYHLL APPARATUS IN DESERT PLANTS.}

\section{ENVIRONMENTAL CONDITIONS IN RELATION TO STRUCTURE.}

The plants which come under observation in this paper are fairly representative of the perennials of the Tucson region (2000 to 3000 feet), with an average rainfall of 12 inches, and occur in a comparatively wide range of habitats. These include the bottom-lands of the Santa Cruz River which are bordering upon the Laboratorv domain; low desert mountains, Tumamoc Hill (a portion of the Laboratory domain); the lower slopes and washes of Tumamoc Hill ; dry, low ridges, the so-called aerial mountain-deltas, which lead eastward from the main range of the Tucson Mountains; the broad and gently rolling mesa or table-land; and, finally, the bed of the Santa Cruz River and certain contiguous irrigating channels and roadside ditches.

In these habitats a relatively large range of environmental conditions are encountered. In them there is a wide variety of soils, of drainage conditions, and of exposure to light and to air-currents. The bottom-lands are characteristically deep and are made up largely of a clay or loam, with strata of sand some distance beneath the surface. Toward the sides of the bottom-lands the top-soil becomes more or less sandy or gravelly, with the coarser material on the slopes immediately above and leading out of the bottoms. Then comes either the mesa with its thin layer of top-soil and a nearly impervious hardpan underlying it, or the lower slopes of the desert mountains, with coarse rock and bowlders and bed-rock, clayish soil, more perfect drainage, and various exposures.

The water-table of the river-bottom lies from 6 to $12 \mathrm{~m}$. from the surface of the soil; that of the mesa is frequently $25 \mathrm{~m}$. and deeper beneath the surface. The location of the reservoirs of water on the mountain have not been determined, but are possibly connected with the fissures and the pockets in the rocks.

Very curiously the leaf-habit of these desert forms, and even their general xerophytic character, are not consistently associated with the character of the habitat. This will be apparent from a few examples. The evergreen habit is not correlated with the conditions of water-supply, or at least with the only sure water-supply - that of the river-bottoms. Of the plants studied in connection with this paper which do not drop their leaves with change of 
seasons, Covillea tridentata (plate 1, B) and Celtis pallida (plate 2, B), the former grows on the mesa and the latter on the slopes of the mountain. Also what is outwardly and palpably the most extreme type of xerophyte, Koberlinia spinosa (plate $3, \mathrm{~A}$ ) having leaves only when in the seedling stage, which is provided with palisade chlorenchyma, a very heavy epidermis, and with deeply sunken stomata, appears most frequently, perhaps, in places where the soil is quite deep. In other words, this form avoids the driest situations. Other forms which are leafless in dry times and therefore the most of the year, as Baccharis cmoryi (and perhaps Aster spinosus should be included, although it has annual subaerial parts), and have xerophytic structure, are to be found only along the river-beds or where the water conclitions are most favorable. Cacti, however, are usually found in dry sit11ations. This is probably associated with their habit of treasuring the scant amount of water as it comes to them from the rains, in place of depending on subirrigation, as in the other forms given. Prosopis, which has a constant as well as abundant water-supply, forms and sheds its leaves with the advent and passing of the seasons in a manner usually and perhaps always quite independent of the time or the amount of the rainfall. Certain of the more gross characters of these desert plants are thus scarcely to be attributed to the molding influenees of the environment; it will doubtless be necessary to take into consideration the peculiar history of each plant, its gradual modification from its remote mesophytic ancestor, before habits and structure are satisfactorily related.

As is well known, a leading feature of the morphology of desert perennials is the reduction of the transpiring surface. Plants may be wholly without leaves, or leaves may be present during early growth or during favorable seasons only, or if leaves are a feature they may be much reduced in size (plate 4). In the former instances the twigs and the branches assume the functions of leaves; in the last case it will be shown in this paper that the same is also true when leaves are present but reduced in size or present during favoring seasons only.

Among other characters which distinguish the leaves of xerophytes is the palisade nature of at least the subepidermal portion of the chlorenchyma. That is, the chlorophyll tissues of the leaf are to a greater or less extent composed of cells whose long axes are placed at right angles to the surface of the leaf. It is of interest, therefore, to learn how far the structure characteristic of the leaves is found in such stems as exercise the function of leaves.

To anticipate one of the findings of this paper, in plants whose transpiring surface is most perfectly reduced the chlorenchyma of the stem is in certain regards very like that in the leaf of the same species; but in those with a more or less pronounced leaf-surface the chlorenchyma of the stem is unlike that of the leaf. In the former ease the stem structure is palisade; in the 
latter it is spongy. The immediate reason for this variation is not clear. The environmental conditions of the two classes of plants may be, as far as one can determine, quite the same. The cause of this must evidently be looked for elsewhere and, as will be shown below, may perhaps be associated with the character of the structures exterior to the chlorenchyma.

A noticeable feature of many of the desert plants as opposed to those of the humid regions - a feature very conceivably related to the distribution of chlorophyll in the stems - is the open character or, in a measure, the looseness of growth. This is characteristic of both trees and shrubs. Among the shrubs this appearance is due in part to the relatively small number of branches and in part to the small size of the leaves. Quite likely the latter is the leading reason in either trees or shrubs. As a result, all portions of the plant are exposed either to direct sunlight or to very strong illumination at all times during the day. The light conditions are such in consequence that wherever chlorophyll is to be found, even in the oldest parts, as it is in Parkinsonia, photosynthesis can take place.

On the other hand, the various positions attained by the branches as related to the incident rays of light insure a certain degree of protection from the most intense light, as is found in such plants as Smilax, of the Florida scrubs, for example, by the erect posture of the leaves.

In considering the affinities of the plants which have been under observation and their distribution, it is of interest to note that their nearest relatives are desert forms. As one result of this fact, the possibility of comparing congeners growing in desert and in humid regions is in many cases precluded and one important source of evidence as to the direct origin of these plants is thrown out. Those plants which are confined to North or South America include Baccharis, Cereus, Condalia, Covillea, Franseria, Krameria, Fouquieria, Koberlinia, and Olneya, which occur in the arid regions of North America only. Ephedra, Prosopis, and Zizyphus have nearly worldwide distribution, since they occur both in the Old and the New Worlds and in both hemispheres, but not in colder regions. Celtis is the only marked exception and has representatives in cold temperate and humid regions, as well as in the warm and dry regions, and is practically cosmopolitan in distribution. 


\section{SCOPE AND PURPOSE.}

Field-studies on the transpiration of desert plants when in a leafless condition, either as a result of the ustual seasonal changes, the advent of drought, or normally without leaves, lead to the discovery that with delicate apparatus* the evolution of watery vapor can be demonstrated when it might be least expected and in surprisingly large amounts. Some of the plants thus studied were Cereus giganteus, Echinocactus wislizeni, Fouquieria splendens, Kócberlinia spinosa, Opuntia versicolor, Parkinsonia microphylla, and others. $t$ This work early suggested an examination into the extent of chlorophyll and the character of the chlorophyll-bearing tissues in the constant parts of the plants. As opportunity offered the work was carried on, and it demonstrated so much of interest that a st1mmary was presented before the Botanical Society of America, New Orleans, December, 1905.

Any satisfactory study of the ehlorophyll relations of the desert plants must take into account the peculiar light conditions to which they are ever exposed. In the present study no attempt has been made to do this, in part because of the complexity of the subject, in part beeause of the lack of satisfactory instruments for making light measurements. It therefore has been limited to an observation of the chlorophyll apparatus as it exists, without reference to correlations other than the obvious biological ones which cropped up everywhere throughout the entire course of the work.

\section{METHODS AND MATERIAL.}

In such a research as the present one living material at hand is a prime necessity, for the reasons, which are very obvious, that chlorophyll can be most satisfactorily identified in living material, and, furthermore, a large quantity of material is a necessity from which to select what is representative as well as by which to know the range in variation of the structures to be studied.

While unusual conditions have been taken into account, this paper aims to present primarily the usual and normal condition of the chlorophyll apparatus. In every instance conclusions were drawn from the study of only normal and healthy plants, and with but one exception (Parkinsonia aculeata) the plants were studied in their proper habitats.

The developmental method of study was employed. That is to say, vigorots branches or stems were selected and sections were made at measured intervals from the tip. Whenever neeessary, comparative observations, in addition, were made on mature structures, so that in each instance the story might be as complete as possible. The presence of chlorophyll in a stem

*Cannon, W. A.: A new method of measuring the transpiration of plants in place. Bull. Torr. Bot. Club, 1905, 32:515.

tCannon, W. A.: On the transpiration of Fonquierias plendens, Bull. Torr. Bot. Club, 1905, 32 : 397; and Biological relations of certain Cacti, The American Naturalist, $1906,40: 27$. 
was determined by inspection only, and all chloroplastids that from comparison were seen to be normally colored were classed as being functional and were considered as having adequate amounts of light and of air.

The following plants were passed uncler observation during the conrse of this study: Aster spinosus Benth.; Baccharis emoryi Gray; Celtis pallida Torr.; Coreus giganteus Englm.; Condalia spathulaca Gray; Covillea tridentata Vail; Ephedra antisyphilitica C. A. Meyer; Fouquicria splendens Englm.; Franseria dumosa Gray; Koberlinia spinosa Zuce.; Krameria canescens Gray; Olneya tesota Gray; Parkinsonia aculeata L.; Parkinsonia microphylla Torr.; Parkinsonia torreyana Watson; Prosopis zelutina Wooton; Salix nigra Marsh.; Sambucus mexicana Pres1.; Zizyphus parryi Torr.

\section{SPECIAL PART: THE CHLOROPHYLL APPARATUS.}

Aster spinosus; BACCHARIS EMORVi. (Fig. I.)

These plants inhabit the wash along the river and the irrigating and wayside ditches, where water is frequently to be found. Aster spinosus is an annual with perennial root; Baccharis cmoryi is perennial. Both Aster and Baccharis are ustually devoid of leaves, but the young portions at least are supplied with rudimentary ones.

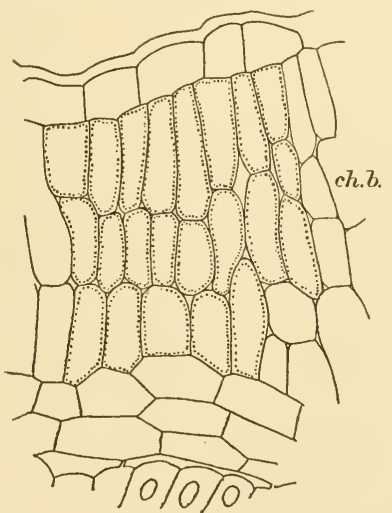

A

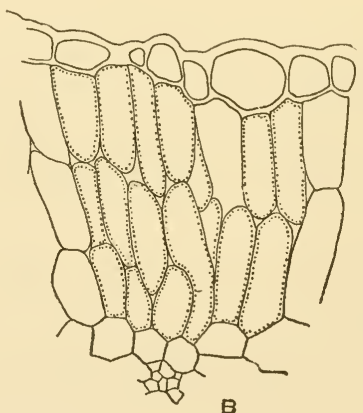

B

FIG. 1.-Baccharis emoryi: $A$, segment from transverse section of young stem to show the character of cortical chlorophyll band (ch.b.); $B$, section of leaf, magnified as in $A$.*

Chlorophyll of the stem is confined to the cortex in both species and in both the chlorenchyma is palisade. The palisade in the stems of each also closely resembles that in the rudimentary leaves of the same species. This similarity in the structure of the chlorophyll band* in the stem and of the 
chlorenchyma of the leaf was observed also in Krameria cancscens, where the cortical chlorophyll band is likewise palisade.

Celtis Pallida. (Plate 2, B, and figs. 2 and 3 .)

The specimen of Celtis which was chosen for study is growing in the arroyo below and to the east of the Laboratory building. A branch about $2 \mathrm{~m}$. in length was selected and sections made at the following distances from the tip: $6,21,34,49,64,79,144$, and $178 \mathrm{~cm}$. The parts of the
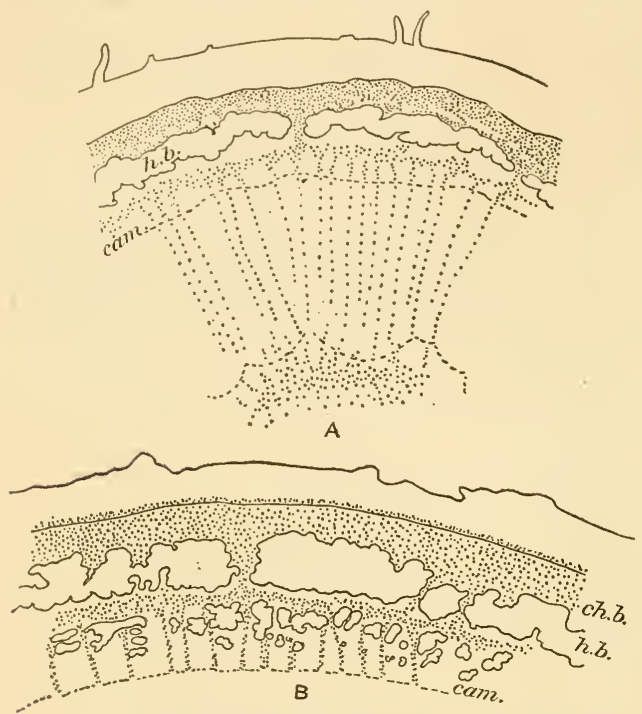

FIG. 2.-Celtis pallida: $A$, section of branch $2 \mathrm{~mm}$. in diameter; $B$, section of branch $3.5 \mathrm{~mm}$. in diameter. branch where the seetions were made had the following liameters: $2,3.5,4,4.5,6$, $8,8.5 \mathrm{~mm}$. and 1 and $1.6 \mathrm{~cm}$, respectively. A section of a branch $2 \mathrm{~mm}$. in diameter and $6 \mathrm{~cm}$. from the tip shows the following general structural relations :

Cortex: There are several well-defined cortical divisions. An epidermis with a thin outer wall and a subepidermal tissueabout three cells in thickness bound the stem. Within this lies a chlorophy 11 band which is also about three cells in thickness. A discontinuous ring of hard bast is situated within the chlorophyll band. Between the hard bast and the cambium is the region of the inner cortical parenchyma.

Woody cylinder: The wood is composed very largely of wood fibers with a noticeably small amount of wood parenchyma. The pith is well marked but does not need further mention in this connection.

Chlorophyll occurs in the outer cortical parenchyma, in much of the parenchyma which lies between the hard bast and the wood, in the medullary rays, both of wood and of cortex, and in the outer cells of the pith.

* The term chlorophyll band as used in this paper refers to that portion of the cortical parenchyma that lies between the epidermis and the ring of mechanical tissue which is about midway between the epidermis and the cambium. It is the largest and the most enduring chlorophyll tissue in the stem. 

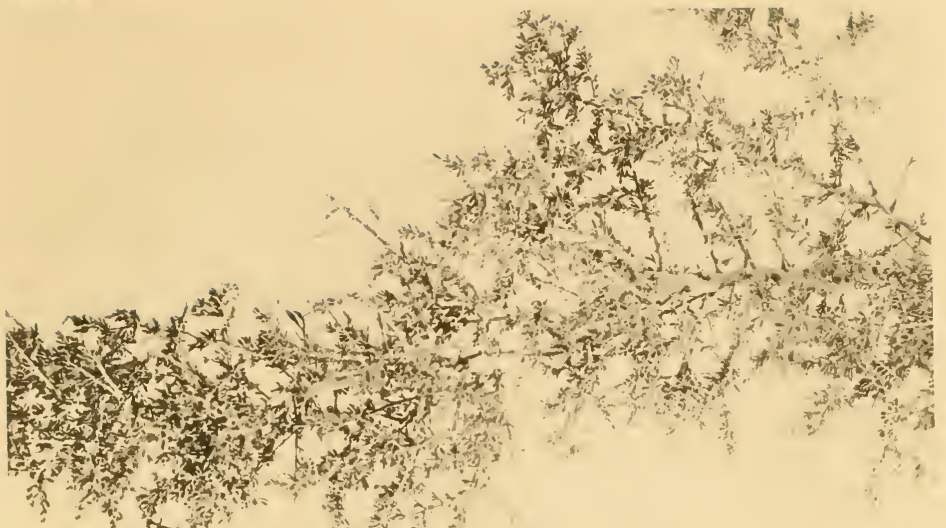
का

A

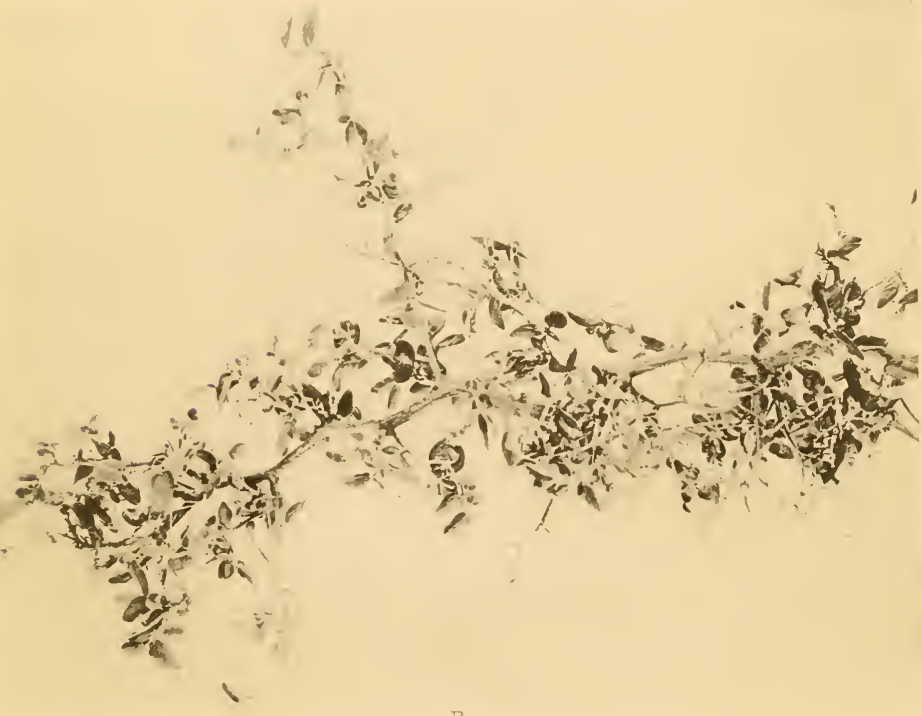

A.- CONDALIA SPATHULACA. Branch from a plant, which is an evergreen, growing on the rocks below and to the north of the laboratory building. April 25, 1907

B.-CELTIS PALLIDA. Portion of a branch from a plant which is growing near the Condalia of "A," showing the character of the leaf-covering. This also is an evergreen. 

With an increase in diameter of the stem characteristic changes take place, more particularly in the cortex, which greatly affect the topography of the chlorophyll apparatus. As the cortex becomes wider, rings of secondary hard bast are formed within the primary ring; parenchyma, which for the most part contains chlorophyll, extends between these rings. The groups of bast are connected in part or always by medullary rays. As the stem increases in diameter these groups are pushed farther and farther apart and the intervening portion becomes filled with parenchyma which contains chlorophyll. In this respect Celtis strikingly resembles Prosopis. The secondary hard bast of the former, however, is not placed as regularly as in Prosopis, and the chlorophyll distribution, consequently, of Celtis is not so symmetrical as in the other species.

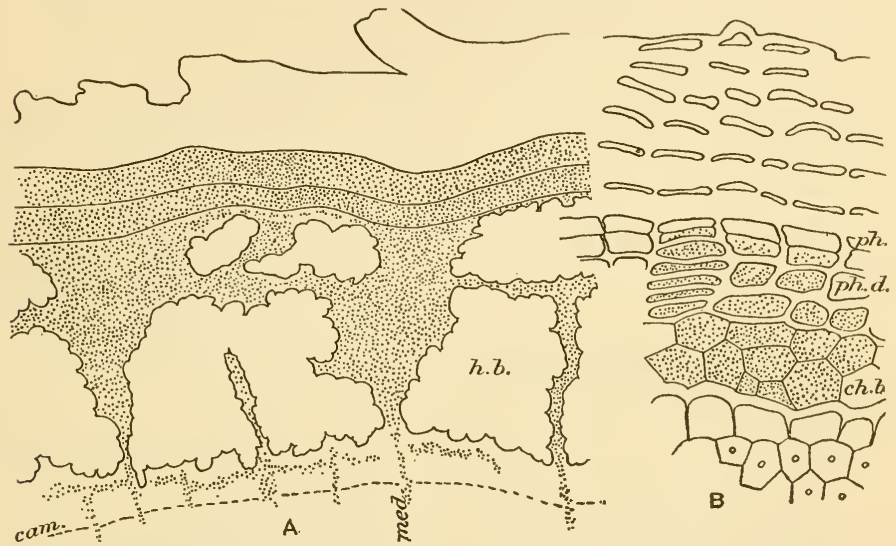

F1G. 3.-Celtis pallida: $A$, section of branch $4.5 \mathrm{~mm}$. in diameter; $B$, detail of $A$, showing presence of chlorophyll in secondary cortex; cam., cambium; ch. b., cortical band of chlorophyll; $h . b$., hard bast; med., medullary ray; $p h$, phellogen; $p h . d$, phelloderm.

But the greatest change in the chlorophyll apparatus occurs as a result of the formation of phelloderm. The cork-cambium arises in the cells immediately outside the chlorophyll band and by its activity gives rise to periderm without and phelloderm within. The latter contains chlorophyll. When the amount of phelloderm about equals the thickness of the chlorophyll band no more appears to be formed. The result is that the chlorophyll band of stems from $4 \mathrm{~mm}$. to $1.6 \mathrm{~cm}$. in diameter is about half phelloderm. How this relation is in older stems was not learned.

How long the chlorophyll remains active in the stem was not determined. It is present in the outer portions of the pith in the stems $8.5 \mathrm{~mm}$. diameter after it has disappeared from the medullary rays, but whether this is a con- 
stant relation was not learned. In a branch $1.6 \mathrm{~cm}$. in diameter, as well as one $1 \mathrm{~cm}$. in diameter, the chlorophyll was confined to the cortex.

The following measurements were made:

\begin{tabular}{|c|c|c|c|c|c|c|}
\hline $\begin{array}{l}\text { Distance } \\
\text { of section } \\
\text { from tip. }\end{array}$ & $\begin{array}{l}\text { Diameler } \\
\text { of stem. }\end{array}$ & $\begin{array}{l}\text { Width of } \\
\text { cortex. }\end{array}$ & $\begin{array}{l}\text { Depth of } \\
\text { phellotierm. }\end{array}$ & $\begin{array}{c}\text { Width of } \\
\text { phelloderm. }\end{array}$ & $\begin{array}{l}\text { Depthof } \\
\text { chloropliyll } \\
\text { band. }\end{array}$ & $\begin{array}{l}\text { Width of } \\
\text { chlorophyll } \\
\text { band. }\end{array}$ \\
\hline $\mathrm{cm} .{ }_{6}$ & $m m_{2}$ & $\begin{array}{l}\mu \\
\ldots \ldots\end{array}$ & $\begin{array}{l}\mu \\
\ldots \ldots\end{array}$ & $\begin{array}{l}\mu \\
\ldots \ldots .\end{array}$ & $\begin{array}{l}\mu \\
78\end{array}$ & $\mu$ \\
\hline 2 I & 3.5 & 320 & ...... & ....... & 96 & 25.6 \\
\hline 34 & 4 & 300 & $54 \cdot 4$ & 39.2 & 89.6 & 28.8 \\
\hline 49 & $4 \cdot 5$ & 415 & 80 & 22.4 & 102.4 & 22.4 \\
\hline 64 & 6 & 547.8 & So & 32 & 102 & 32 \\
\hline 79 & 8 & 547.8 & $7^{6} .8$ & I 9.2 & 96 & 35.2 \\
\hline 144 & 10 & $5^{81}$ & 80 & 28 & 108.8 & 25.6 \\
\hline 178 & 16 & 1079 & II 8.4 & 28.8 & 147.2 & 32 \\
\hline
\end{tabular}

Condalia spathulaca. (Plate 2, A, and fig. 4.)

The plant from which the branch studied was taken is growing by the Hospital Road near the northeast corner of the Laboratory domain. The shrub is about $1.5 \mathrm{~m}$. high and is a very vigorous one.

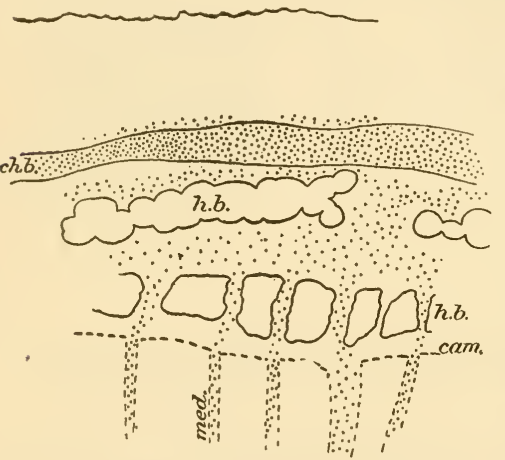

FIG. 4.-Condalia spathulaca: Section from a branch $2 \mathrm{~mm}$. in diameter.

Sections were made at the following distances from the tip: $2,5,20,35,65,95 \mathrm{~cm}$. These were $1.5,2,4,7.5 \mathrm{~mm}$. and 1.2 , $1.7 \mathrm{~cm}$. in diameter, respectively.

A cross-section of a young branch $1.5 \mathrm{~mm}$. in diameter and $2 \mathrm{~cm}$. from the tip shows the following leading structural characters: An epidermis with a thin cuticle bounds the stem. Within this is a hypodermal portion three cells thick, and within this, again, is a collenchyma-like tissue about as thick. The chlorophyll band, about three cells wide, lies immediately within the last-mentioned tissue and occupies the central portion of the cortex. A relatively narrow inner cortical portion separates the chlorophyll band from the cambium. This inner part consists of a discontinuous hard-bast ring and thin-walled parenchyma. The former abuts on the chlorenchyma. The wood and the pith present no characteristics of interest in the present connection. In addition to the chlorophyll band, chlorophyll occurs also in most of the inner cortical parenchyma, in the medullary rays of the wood, and in the outer pith-cells. 
The chlorophyll band is a relatively narrow tissue which lies rather deeply in young stems, but in older ones much nearer the surface (see table of measurements below). The eells are either euboid or slightly elongated. If the latter the long axis is tangential to the surface.

With increase in diameter certain ehanges take place in the stem which are most marked in the eortex. Cork is formed in very small stems. In a stem $2 \mathrm{~mm}$. in diameter and $5 \mathrm{~cm}$. from the tip it was observed in the hypodermal cells, where a considerable amount of periderm was organized. This is more pronounced in branches $4 \mathrm{~mm}$. and still more in those $7.5 \mathrm{~mm}$. in diameter. The phelloderm, however, is not formed until the stem is somewhat older. In a stem $1.2 \mathrm{~cm}$. in diameter the phelloderm was about two cells in thickness and was chlorophyll-bearing; in a branch $1.7 \mathrm{~cm}$. in diameter the amount of chlorophyll-bearing phelloderm was so great as to considerably increase the width of the ehlorophyll tissues. The chlorophyll early leaves the wood and the pith; in a stem only $7.5 \mathrm{~mm}$. in diameter it was confined to the outer portion of the cortex.

The following measurements were made:

\begin{tabular}{|c|c|c|c|c|}
\hline $\begin{array}{l}\text { Diameter } \\
\text { of braneb. }\end{array}$ & $\begin{array}{l}\text { Distance } \\
\text { from tip. }\end{array}$ & $\begin{array}{l}\text { Width of } \\
\text { cortex. }\end{array}$ & $\begin{array}{l}\text { Width of } \\
\text { chlorophyll } \\
\text { band. }\end{array}$ & $\begin{array}{l}\text { Depth of } \\
\text { ehlorophylI } \\
\text { band. }\end{array}$ \\
\hline$m m$. & $\mathrm{cm}$. & $\mu$ & $\mu$ & $\mu$ \\
\hline I. 5 & 2 & 208 & $3^{8.4}$ & 70 \\
\hline 2 & 5 & 256 & 32 & So \\
\hline 4 & 20 & $44^{8} .2$ & 25.6 & 64 \\
\hline $7 \cdot 5$ & 35 & 1162 & 64 & 64 \\
\hline 12 & 65 & I 494 & 80 & 19.2 \\
\hline 17 & 95 & I 147 & 73.6 & 41.6 \\
\hline
\end{tabular}

\section{Covillea tridentata. (Plate $1, \mathrm{~B}$, and fig. 5.)}

The plant from which the branch studied was taken is growing near the road a few meters east of the Laboratory building. Sections were cut at the following distances from the tip: 5, 10, 20, 35, 65, $95 \mathrm{~cm}$, and were $1,1.5,3,4.5,7.5,9.5 \mathrm{~mm}$., respectively, in cliameter.

The young and angular stem, $1 \mathrm{~mm}$. in diameter, has the following general relations of its tissues: Within the epidermis, which has a rather thin cuticle, lies the broad chlorophyll band, which is about three cells in thickness. A discontinuous hard-bast ring is placed immediately within the chlorophyll band. This is made up of larger and of smaller groups, of which the former lies opposite the angles of the stem. More or less stony tissue also is found in the same ring. Between the groups of mechanical tissue is thin-walled parenchyma. Within the hard-bast ring, and separating it from the cambium, are the distal ends of the medullary rays and parenchyma between them. There is nothing noteworthy in the present eonneetion regarding either pith or wood. 
The chlorophyll band is made up of cuboid and elongated cells, of which the latter have the long axis placed parallel to the surface of the stem. In addition to the outer chlorophyll band, chlorophyll is found sparingly in the medullary rays both of the cortex and of the wood and in the pith also.

With increase in diameter the stem exhibits certain changes in its general structure, of which the most important in the present eonnection are to be found in the cortex. Cork is organized early and is superficial. The phelloderm is in direct contact with the chlorophyll band and probably contributes chlorophyll-bearing cells to the latter, although this was not definitely determined. The other changes in the cortex do not affect the distribution of the chlorophyll and may be neglected.

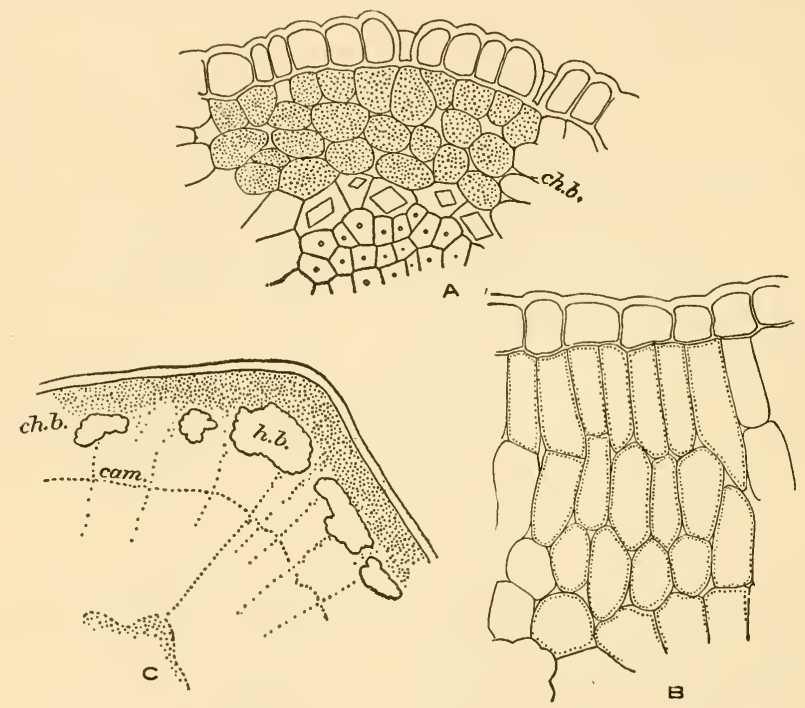

FIG. 5.-Covillea tridentata: $A$, transverse section of stem $5 \mathrm{~mm}$. in diameter, showing character of spongy tissue of chlorophyll band; $B$, transverse section of leaf, showing palisade character of subepidermal chlorenchyma; $C$, cross-section of stem $\mathrm{x} \mathrm{mm}$. in diameter, to show general distribution of chlorophyll. Lettered as in fig. 3 .

The order of disappearance of chlorophyll from the stem was not followed. In a stem $1.5 \mathrm{~mm}$. in diameter chlorophyll was observed in the pith, in the medullary rays of wood and of cortex, and in the chlorophyll band. In a stem $3 \mathrm{~mm}$. in diameter, however, it had practically disappeared from all tissues deeper in the stem than the chlorophyll band; in a stem $9.5 \mathrm{~mm}$. in diameter no traces of chlorophyll were to be detected outside of this band. No chlorophyll was found in another branch $2 \mathrm{~cm}$. in diameter and $145 \mathrm{~cm}$. from the tip, although the primitive chlorophyll band, but without chlorophyll, was still present. 
The following measurements were made:

\begin{tabular}{|c|c|c|c|c|}
\hline $\begin{array}{l}\text { Diameter } \\
\text { of branch. }\end{array}$ & $\begin{array}{l}\text { Distance } \\
\text { from tip. }\end{array}$ & $\begin{array}{l}\text { Width of } \\
\text { cortex. }\end{array}$ & $\begin{array}{l}\text { Wldth of } \\
\text { ehlorophyll } \\
\text { band. }\end{array}$ & $\begin{array}{l}\text { Depth of } \\
\text { eblorophyll } \\
\text { band. }\end{array}$ \\
\hline $\mathrm{mm}$. & $\mathrm{cm}$. & $\mu$ & $\mu$ & $\mu$ \\
\hline I & 5 & $17^{6}$ & $4^{8}$ & 16 \\
\hline I. 5 & 10 & 256 & I I 8 & 19.2 \\
\hline 3 & 20 & 332 & 64 & $4^{8}$ \\
\hline $4 \cdot 5$ & 35 & $42 \mathrm{I}$ & 80 & 80 \\
\hline $7 \cdot 5$ & 65 & 421.6 & 64 & 32 \\
\hline $9 \cdot 5$ & 95 & 664 & 64 & 80 \\
\hline
\end{tabular}

Ephedra antisyphilitica. (Fig. 6.)

Ephedra occurs in the wash at the foot of Tumamoc Hill, to the west of the Laboratory. The specimen selected for observation forms a dense shrub about $2 \mathrm{~m}$. high, which has found refuge from predatory cattle by growing under a large Acacia greggii. As is well known, the plant has an appearance much like that of scouring rush, which is due to the numerous slender branches that are divided into sections of about $50 \mathrm{~cm}$. each. These branches are the only green ones on the plant; the older ones are covered with a rough bark, which is of gray color.

The general structure of one of the green branches may be outlined as follows: An epidermis with heavy cuticle and with deeply sunken stomata bound the stem. The stomata are regularly disposed in a manner depending on the arrangement of certain mechanical tissues within the cortex. I refer to bundles of fibers which occur at intervals of about $50 \mu$ on the inner edge and abutting on the epidermis. Between the bundles the surface of the stem is somewhat depressed and in these channels the stomata are placed. The cortex is composed mainly of palisade cells which are chlorophyllaceous, but fibers in groups are scattered in an irregular fashion through the cortex. The wood and the pith in young stems do not contain chlorophyll; in older stems, however, the medullary rays of the wood are supplied with chlorophyll.

The younger portions of the green branches, with a diameter of $1 \mathrm{~mm}$., have chlorophyll in the cortex only and, as mentioned above, this is palisade. The cells range in length from $15 \mu$ to $65 \mu$, and of these the shorter are uniformly near the woody cylinder. In stems $1.5 \mathrm{~mm}$. in diameter the inner cells have lost their palisade character and are more or less cuboid. This is probably owing to the growth in diameter of the stem and to the consequent tangential stretching and radial compression of the cortex. Finally, these inner cells become elongated in a direction parallel to the surface, so that their primitive character is wholly lost.

In stems $2 \mathrm{~mm}$. in diameter the diameter of the woody cylinder and the thickness of the cortex are noticeably increased as a result of the activity of the cambium. The topography of the chlorophyll apparatus is likewise 
somewhat changed, since it has been extended to include the medullary rays of both wood and cortex. The organization of the phelloderm, which may be observed in stems $4 \mathrm{~mm}$. in diameter, also modifies the chlorophyll distribution. The phellogen extends from the outer part of the subepidermal palisade layer to about the layer of cells which is next to the inner chlorophyll-bearing cells. In the outer cells the outer ends are converted
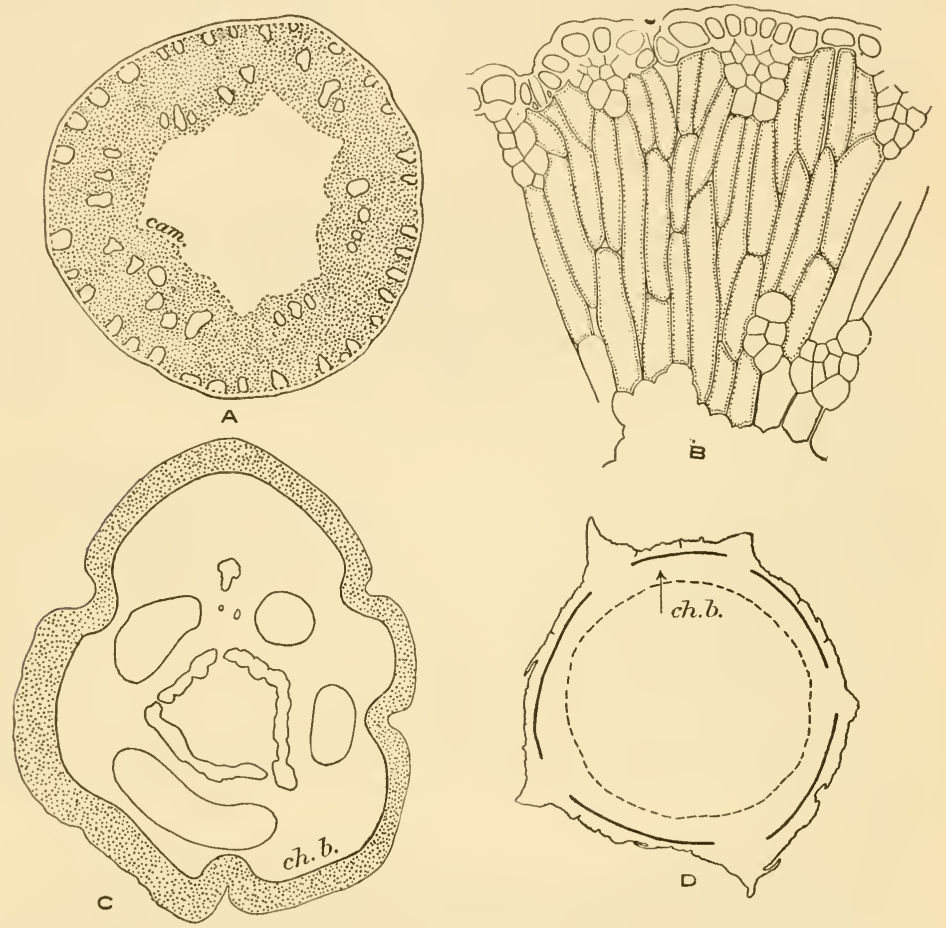

FIG. 6.-Ephedra antisyphilitica: $A$, cross-section of green branch, a detail of which is shown in $B$. $B$, portion of stem to show structure of chlorophyll band of cortex. Fouquieria splendens: $C$, transverse section of stem $5 \mathrm{~mm}$. in diameter; bases of stout spines which entirely encircle stem are not shown. D, section of older stem in which the chiorophyll band has become discontinuous as a result of the stem's growth (see text). ch.b., cortical chlorophyll band; cam., cambium.

by transverse walls into phellogen; in the inner cells, however, which have the long axis parallel to the surface in stems of this size, the division walls forming the phellogen are parallel to the long diameter of the cells. The bark thus originating is lens-shaped. It therefore happens that a crosssection of a stem $4 \mathrm{~mm}$. in diameter shows a portion of the primitive cortex with chlorophyll-bearing cells and a portion of it converted into cork which 
is, of conrse, without chlorophy11. However, at this time, in addition to segments of the original chlorophyll band, there extends beneath the cork at least one layer of cells which are chlorophyllaceous. It does not appear that the phelloderm contributes to the chlorophyll apparatus. From these circumstances it happens that stems which appear brown or gray in color and give no visible indication of chlorophyll are, however, chlorophyllaceous.

With the further derelopment of the bark the primary cortex, except the single layer of cells which contain chlorophyll and which lic immediately within the phellogen, is entirely cut off, and with this process the most considerable portion of the chlorenchyma of the stem disappears. When chlorophyll quite left the stem was not learned. In a stem $7.5 \mathrm{~mm}$. in diameter, in which no trace of the primary cortex remained, ehlorophyll was to be seen in the outer medullary rays of the woody eylinder, in the rays of the cortex, and sparingly in parenchyma connecting the ends of the latter. Stems 1.1 and $1.5 \mathrm{~cm}$. in diameter give no trace of ehlorophyll in either wood or pith.

FouQuieria SPLENDENS. (Fig. 6.)

Fonquicria oceurs on dry, well-drained slopes. The plant used in this study is growing on Tumamoc Hill not far below the Laboratory.

The young stem, $5 \mathrm{~mm}$. in diameter, is characterized by three welldefined areas, namely, (1) an external shell of selerenchyma, within which is (2) parenchyma containing chlorophyll, and within this is (3) the inner cortex, wood, and pith. The relative extent of the three divisions will be apparent from the sketches. The external shell is part of the primary cortex and is morphologically the base of the spines of the stem, which in turn are morphologically midribs of the primary leaves. The cells of the external shell early take on the characteristic thickening and turn brown, and in stems $5 \mathrm{~mm}$. in diameter the shell forms a continuous covering. When the stem increases in diameter, however, the mass of selerenchyma connected with each spine draws away from the mass connected with every other spine, and the intervening space is occupied by a waxy tissue which is somewhat greenish. The area covered by these two classes of tissue is more and more disproportionate in amount as the stem grows until in the oldest parts the surface is practically all covered by the newer tissue.

The chlorophyll is confined to the parenchyma, which lies immediately within the shell of selerenchyma or the newer tissue that succeeds it. It is composed wholly of cuboid, thin-walled cells with prominent intercellular spaces.

So far as I have observed, chlorophyll is always present in the stems of Fouquieria, of whatever size. In stems $5 \mathrm{~mm}$. in diameter the chlorophyll band forms a continuons ring in the outer portion of the cortex. As the shell base of each spine becomes separated from the base of the other contiguous spines in the manner above described, breaks occur in the chloro- 
phyll band opposite the center of each sclerenchyma mass, due perhaps to the fact that the covering of the chlorophyll band at that point is heavy and opaque, so that the chlorophy11 in the older stems oceurs opposite the newer external tissue only (fig. 6, D). This circumstance, together with the translueent condition of the newer portion of the external covering, is largely responsible for the green coloring of the older parts of the plant.

The following measurements were taken:

\begin{tabular}{|r|r|c|}
\hline $\begin{array}{r}\text { Diameter } \\
\text { of stem. }\end{array}$ & $\begin{array}{c}\text { Width of } \\
\text { exterior } \\
\text { covering. }\end{array}$ & $\begin{array}{c}\text { Depth of } \\
\text { chlorophyll } \\
\text { in the stem. }\end{array}$ \\
\cline { 1 - 2 }$m n^{m}$. & $\mu$ & $\mu$ \\
5 & 498 & 818 \\
8 & 500 & 832 \\
30 & 1162 & 894 \\
\hline
\end{tabular}

Franseria dumosa. (Plate 3 , B, and fig 7.)

Franseria is a globoid shrub about $50 \mathrm{~cm}$. high which is growing in some abundance on the north slopes of Tumamoc Hill and on the aerial mountain-deltas in the western portion of the Laboratory reservation. It is characterized by numerous slender branches of approximately equal length, which spring either from the short main stem or from the bases of the older branches. It thus happens that new branches may replace dead ones and maintain the usual form of the plant when the latter fall away. The triangulate leaves are sage-colored, and for the most part are borne near the tips of the branches, although there is great variation in this regard, depending apparently on the adequacy of the water-supply. In times of extreme drought only small leaves remain on the very tips of the branches.

The external tissues of the branch vary with its age and presumably with the conditions under which growth took place. The most recent portions are green and dark purple in color. The surface has a shining or waxy appearance, due to secretions from hairs, certain of which are provided with chlorophyll (fig. 7, c). Below the younger portions the branch is roughened by narrow longitudinal furrows and ridges, the latter of which are continuations of the epidermis. This condition marks the first appearance of bark. Towards the base of the stem the furrows widen, the ridges disappear, and the entire surface becomes black and of a shaggy character. As will be shown below, chlorophyll oceurs in the cortex up to the last condition of the bark given. With scarcely an exeeption chlorophyll is found in the cortex within 2 to $5 \mathrm{~cm}$. of the bases of the secondary branches, from which it follows that a very large percentage of the entire carbon assimilative area of this plant, as Fouquieria and others, must be in its branches.

The general structural characteristics of the branches, particularly of the cortex, are indicated by the accompanying sketehes and may be outlined 

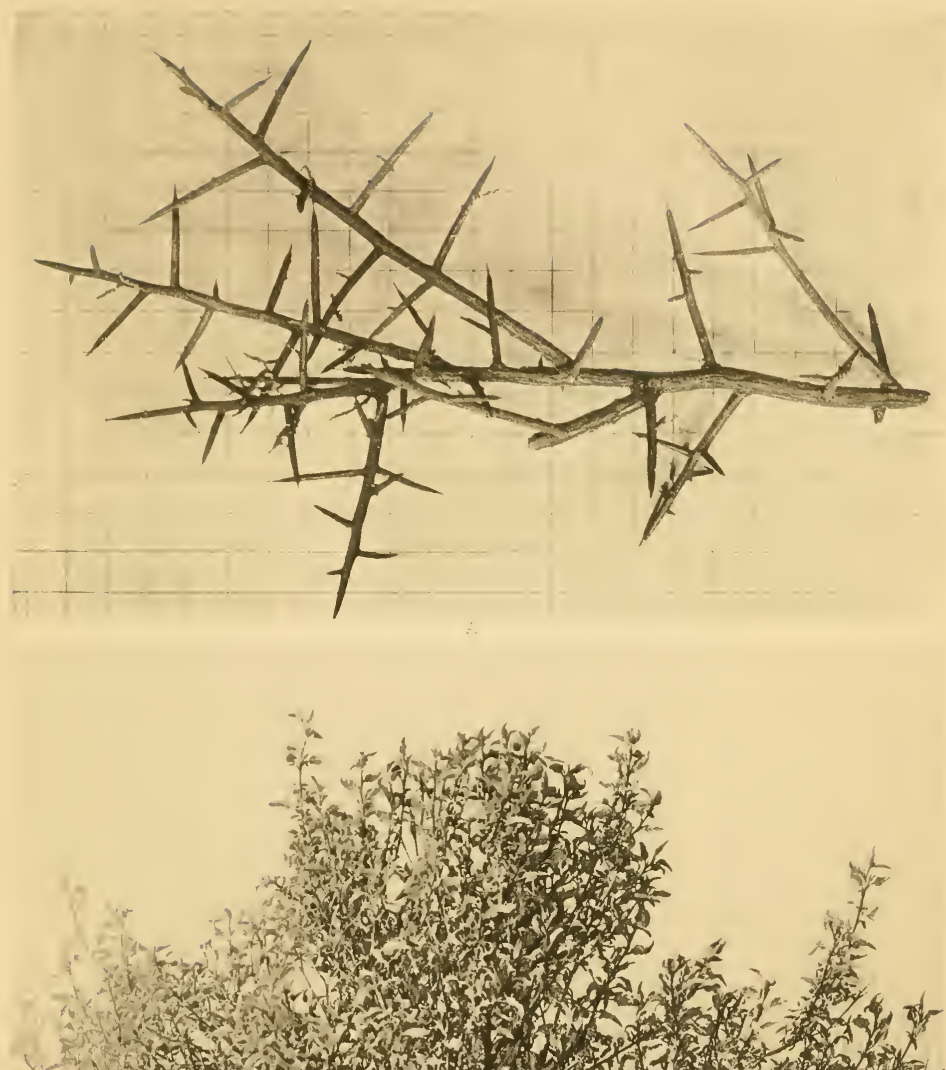

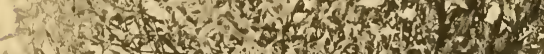
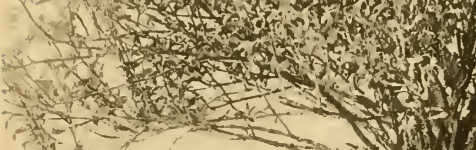

1ete Fis
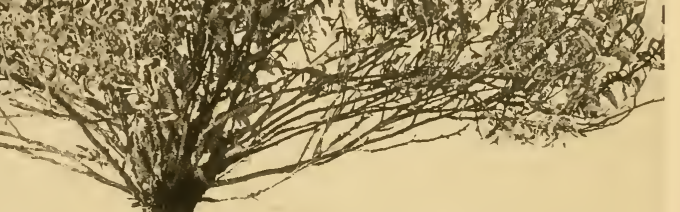

A. - KEEBERLINIA SPINOSA. Branch from a plant which is situated on the old Ft. Yuma Road along the bottom land of the Santa Cruz River. Nov, 8, 1906.

B.-FRANSERIA DUMOSA. An entire plant taken from the northern slope of the Tumamoc Hill. April 25, 1907. Franseria is an evergreen. 

as follows: The epidermis has a relatively thin euticle. At a distance of $1.5 \mathrm{~cm}$. from the tip its contents are colorless, but in the older parts a dark purple pigment is present. As previously mentioned, multicellular hairs and other hairs occur; these are to be found most abundant, perhaps, where no pigment is present in the epidermis. The secretion from these hairs, which is soluble in chloroform and ether, is so copious as to nearly submerge them, and covers the stem as far as the location of cork. The cortex

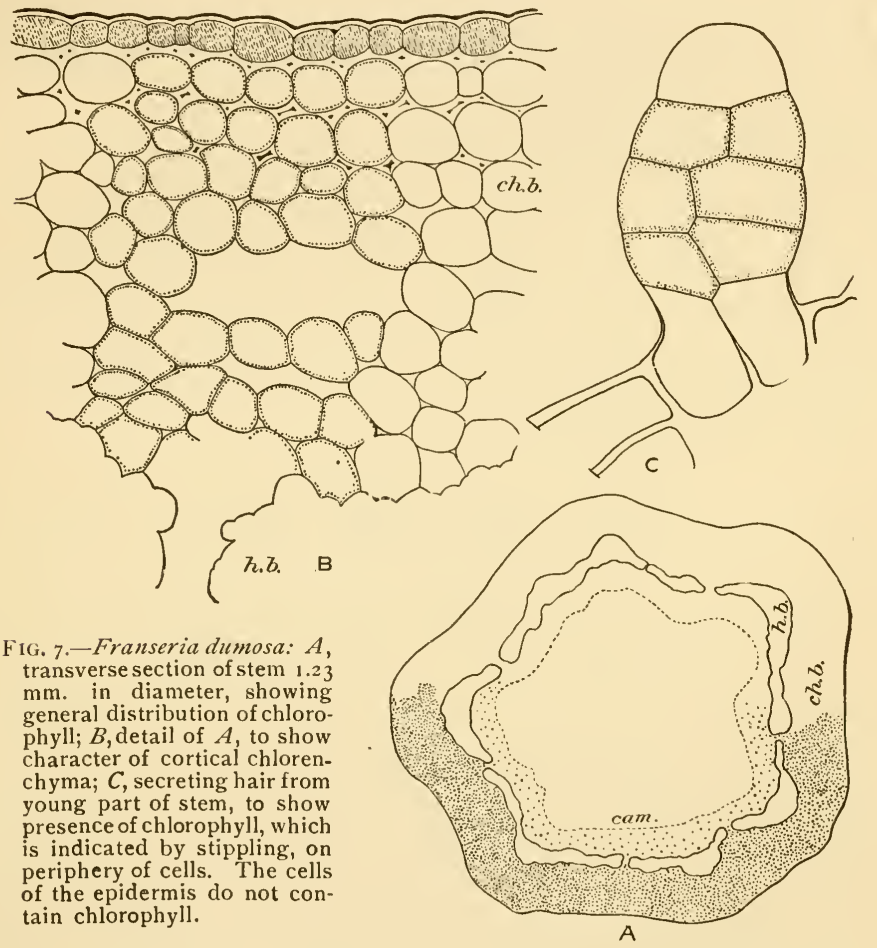

in stems $1.23 \mathrm{~mm}$. in diameter and $5 \mathrm{~cm}$. from the tip is composed of four - well-defined tissues, which, enumerated from without, are collenchyma, parenchyma, hard bast, and soft bast. The collenchymatous and the parenchymatous portions are chlorophyll-bearing; some chlorophyll may also be found in the ground-tissue between the hard bast and the cambium. The parenchyma exterior to the hard bast contains chlorophyll and is made up of cuboid cells with large intercellular spaces. 
Except in the very youngest branches, $i$. $c$., those less than $1.13 \mathrm{~mm}$. in diameter, no chlorophyll occurs either in pith or wood, but in a section of this diameter it was observed in both. It oceurred in the outer cells of the pith and in the primary medullary rays of the wood, as well as in parenehyma between the duets.

The formation of cork and the activity of the cambium make important modifications in the chlorophyll apparatus as above described. The cork cuts off all tissue exterior to the ring of hard bast. There does not appear to be a definite cork-cambium, but the cortical cells are directly converted into cork. About the time cork is formed the parenchymatous cells within the hard-bast ring become much enlarged, the chlorophyll content is greatly increased, and these cells replace in function the primary chlorophyll band, which has become cork. Through the activity of the cambium more deeply placed chlorenchyma and hard-bast rings are formed, which eventually replace the secondary chlorenchyma much as the latter has replaced the primary chlorenchyma. The exfoliating process appears to be repeated several times, until in the oldest portions of the branch the portions ent off and those reformed no longer contain chlorophyll. In this repeated formation, destruction, and reformation of chlorenchyma Franscria is peculiar among the plants observed.

The following measurements were made:

\begin{tabular}{|c|c|c|c|}
$\begin{array}{c}\text { I)iameter } \\
\text { of branch. }\end{array}$ & $\begin{array}{c}\text { I)istance } \\
\text { of section } \\
\text { from tip. }\end{array}$ & $\begin{array}{c}\text { Depth or } \\
\text { outer chlor- } \\
\text { ophyll } \\
\text { band. }\end{array}$ & $\begin{array}{c}\text { Width of } \\
\text { cortex. }\end{array}$ \\
\hline mm. & $\mathrm{cm}$. & $\mu$ & $\mu$ \\
\hline 1.13 & 1.5 & 21 & $\ldots \ldots$ \\
1.23 & 5 & 26 & 294 \\
1.67 & 11 & 126 & 525 \\
2.46 & 15 & 231 & 588 \\
\hline
\end{tabular}

Kéberlinia spinosa. (Plate 3, A, and fig. 8.)

Keberlinia, leafless except in seedling stage, occurs as isolated plants mainly in the bottom-lands of the river. It avoids for the most part the dry slopes of the mountains and the mesa. The plant studied is growing near the southeast corner of the cemetery at Tueson. It is about $1.5 \mathrm{~m}$. high and extends horizontally, so that the diameter of the shrub may perhaps be $3 \mathrm{~m}$. The shrub has in consequence a squat appearanee.

In structure Koberlinia shows several striking characters. A crosssection of a branch $3.5 \mathrm{~mm}$. in diameter and $5 \mathrm{~cm}$. from the tip has in the cortex four well-marked regions. It is bounded by an epidermis with a very heavy cuticle, from 80 to $96 \mu$ thick, which is piereed by stomal canals. Immediately beneath the epidermis and reaching to it is a band of chlorophyll nearly $0.2 \mathrm{~mm}$. in breadth. This band is bounded on its inner surface by 
a ring of mechanical tissue composed of hard bast connected by grit-cells, and within this ring is the thin-walled parenchyma, which separates the hard-bast ring from the cambium. Medullary rays reach to the ring of mechanical tissue. The wood and the pith exhibit no features of interest in this study.

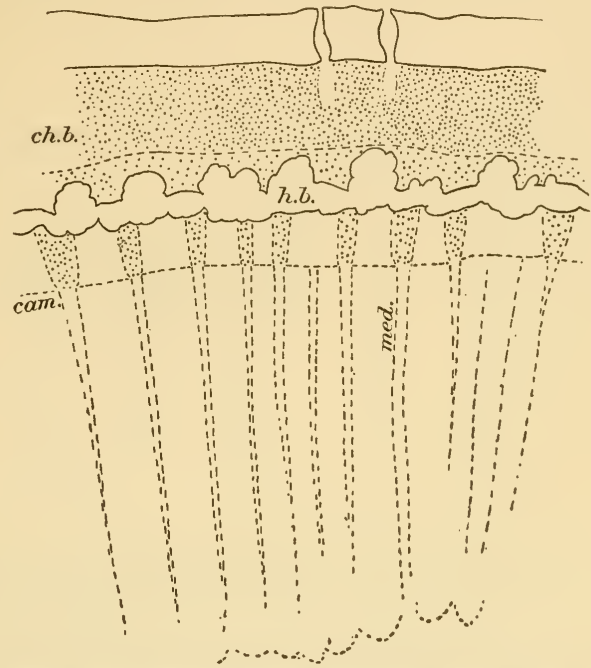

F1G.8.-Koberlinia spinosa: Segment from cross-section of stem $1.5 \mathrm{~mm}$. in diameter, to show distribution of chlorophyll.

The chlorophyll is practically wholly limited to the cortex. If it is found in the wood at all it is in the outermost medullary rays. The most important chlorophyll-bearing tissue is the subepidermal band which occupies the area between the epidermis and the hard-bast ring. The outer cells are palisade in form; the inmost three layers are spongy chlorenchyma or they may be elongated in a tangential direction. The parenchyma, which occurs opposite the grit-cells, and therefore between the hard-bast groups, although forming a part of the chlorophyll band, are morphologically the outer ends of the cortical medullary rays. The cells referred to are exterior to the grit-cells and have become detached from the medullary rays by the assumption of heavy walls by that part of them which lies between the hard-bast groups.

With increased diameter certain changes in the relations of the chloropyl1bearing tissues of the stem take place. The heavy cuticle becomes ruptured at frequent intervals and the spaces thus formed are covered by a manylayered periderm. The cork-cambium arises in the epidermis. As more 


\section{Olneya tesota.}

Olneya is a small tree of which but a single spccimen is growing near the Laboratory domain. There is a grove of this species at Robles Pass, Tueson Mountains, and another east of Pima Canyon, Santa Catalina Mountains. These habitats are rocky lower mountain slopes; it does not occur in this vicinity on the bottom-lands of the river or on the mesa.

Branches $1.5 \mathrm{~mm}$., $4 \mathrm{~mm} ., 5.5 \mathrm{~mm}$., $9 \mathrm{~mm} ., 1.15 \mathrm{~cm} ., 1.35 \mathrm{~cm}$., and $2 \mathrm{~cm}$. in diameter were studied; the sections were cut the following distances from the tip: $1,20,35,50,65,90$, and $120 \mathrm{~cm}$.

A stem $1.5 \mathrm{~mm}$. in diameter is characterized by an epidermis not well defined, by a chlorophyll band that is frequently interrupted by masses of collenchyma, and by a relatively narrow inner cortical portion. The wood has a large proportion of wood parenchyma. The medullary rays extend to the chlorophyll band of the cortex through the gaps in the hard-bast ring.

In addition to there being chlorophyll in the so-called chlorophyll band of the cortex, it is to be found in branches $1.5 \mathrm{~mm}$. in diameter in the medullary rays of the cortex, but not in the wood or the pith. In branches $4 \mathrm{~mm}$. in diameter and $20 \mathrm{~cm}$. from the tip, however, chlorophyll was seen in the medullary rays of the wood and in the wood parenchyma.

A characteristic change in the distribution of the chlorophyll in the stem and in its relations to various tissues takes place with increase in diameter. As the circumference becomes greater the groups of hard bast are pulled farther and farther apart, the spaces between are filled with parenchyma, and as this tissue is really the distal ends of the medullary rays, the latter in older stems become fan-shaped. This condition recalls that observed in Celtis and in Prosopis. The chlorenchyma is increased in amount by the activity of the cork-cambitum also. Periderm is to be seen in stems $9 \mathrm{~mm}$. in diameter. It is formed by the subepidermal phellogen, which also gives rise to phelloderm that contains chlorophyll. In the older stems the chlorophyll band is about one-half periderm and one-half primary cortex.

The chlorophyll early disappears from the woody cylinder. In a branch $9 \mathrm{~mm}$. in diameter it could be found in neither pith nor wood, and in branches $2 \mathrm{~cm}$. in diameter it was confined to the outer portion of the cortex and did not appear to be functional.

The following measurements were taken:

\begin{tabular}{|c|c|c|c|c|}
\hline $\begin{array}{l}\text { Distance } \\
\text { from tip. }\end{array}$ & $\begin{array}{l}\text { Diameter } \\
\text { of branch. }\end{array}$ & $\begin{array}{l}\text { Width of } \\
\text { cortex. }\end{array}$ & $\begin{array}{l}\text { Width of } \\
\text { chlorophyll } \\
\text { band. }\end{array}$ & $\begin{array}{l}\text { Depth of } \\
\text { chloropliyll } \\
\text { band. }\end{array}$ \\
\hline : $\mathrm{cm}$ & $\begin{array}{l}\mathrm{mm} . \\
\mathrm{I} .5\end{array}$ & ${ }_{I 60}^{\mu}$ & $\begin{array}{c}\mu \\
4^{8}\end{array}$ & $\begin{array}{l}\mu \\
3^{S} .4\end{array}$ \\
\hline$\therefore 20$ & 4 & 415 & 8o & 32 \\
\hline$=35$ & $5 \cdot 5$ & 498 & $54 \cdot 4$ & 48 \\
\hline 50 & 9 & 7 So & II 8.4 & 70.4 \\
\hline$=65$ & I. 15 & 1079 & 160 & 64 \\
\hline 90 & 1. 35 & 1162 & 160 & 64 \\
\hline 120 & 20 & 1660 & I 60 & 96 \\
\hline
\end{tabular}


Parkinsonia aculeata, P. microphylla, and P. TORReyana.

(Plate 4 and figs. ro and ir.)

Parkinsonias are small trees which occur in this vicinity in habitats that usually are distinct. $P$. aculeata is found native on the lower slopes of the
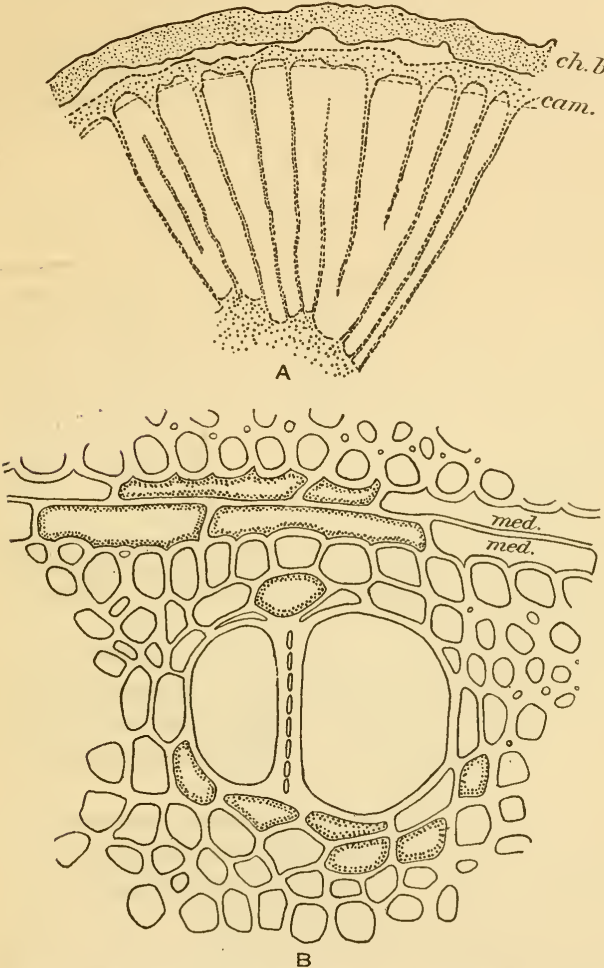

mm. in diameter; $B$, transverse section of woody cylinder to show presence of chlorophyll in wood parenchyma adjoining a duct and in the medullary rays. As in all the other sketches the stippling indicates the presence of chlorophyll. dantly supplied with chlorophyll, which is distributed in characteristic fashion from epidermis to pith. In general terms this distribution may be defined as follows: It occurs in the cortex as three separate bands concentrically placed in the medullary rays of cortex and of wood, in certain of the wood parenchyma, and in the pith. This is the maximum chlorophyll 50 miles west of Tueson, but is cultivated in the gardens of the city. $P$. microphylla occurs on Tumamoc Hill and on the low, dry hills in the western portion of the Laboratory domain, $P$. torreyana is growing in the wash at the western base of Tumamoc Hill. The three species are green in all parts, from which the common name, palo verde, is derived. P. aculeata and torreyana carry more leaf-surface, or at least larger leaves, than microphylla, in which they are extremely small. In each species portions or all of the leaves fall away during unfavorable seasons. The general structural relations of the stem do not need special notice; they will be apparent from the discusapparatus.

Young branches, i. $e$., those $1 \mathrm{~cm}$. or less in diameter, are abun-

Coyote Mountains, about 
distribution, but in older stems, owing to changes in structure incident to growth and development by which the various chlorophyll-bearing tissues are eliminated or lose their chlorophyll contents, this distribution is greatly modified.

The epidermis is usually or at least frequently well supplied with chlorophyll. This applies to stems $1 \mathrm{~cm}$. or less in diameter, although a branch of $P$. torreyana was examined which was $2.25 \mathrm{~cm}$. in diameter and which, nevertheless, still had chlorophyll in the epidermis. It may be remarked in passing that this branch showed another characteristic which is unusual in Parkinsonia-the woody cylinder did not contain chlorophyll. As will appear later, in the ordinary sequence of the disappearance of chlorophyll from the stem, the epidermis leads, followed by the pith and the wood.

The most prominent mass of chlorophyll-bearing tissue in the stem, and the one that gives the color characteristic of the tree, is the outer cortical chlorophyll band. Also, this chlorophyll tissue is the most enduring. It has been identified in stems $8 \mathrm{~cm}$. in diameter, and is present in the oldest parts,

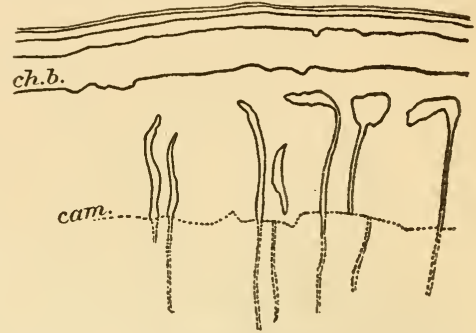

FIG. Ir.-Parkinsonia torreyana: Segment of stem $7 \mathrm{~mm}$. in diameter, to show the distribution of chlorophyll. Lettered as in preceding figures. even in some or perhaps most instances within a few centimeters of the very base of the tree. It varies in width from $83 \mu$ to $246 \mu$ and its outer surface lies from $83 \mu$ to $500 \mu$ beneath the surface of the stem. In structure the chlorophyll band is wholly of spongy tissue. The cells are cuboid and thin-walled.

Within the outermost band of chlorenchyma is a ring of mechanical tissue composed of alternating groups of hard bast and of heavy-walled parenchyma (which later become grit-cells?). A second band of chlorenchyma lies immediately within this mechanical stratum, which for convenience will be termed the median band of chlorenchyma. In the younger stems the median band is practically continuous, but in the older ones it becomes broken up into distinct masses. From the median band there passes inward, like the spokes of a wheel, the medullary rays of the inner part of the cortex. These rays in the younger branches are well supplied with chlorophyll.

Turning now to the woody cylinder, we find that the medullary rays, a portion of the wood parenchyma, and the pith are chlorophyll-bearing. In branches $1 \mathrm{~cm}$. in diameter the entire medullary ray from cortex to the pith is so well provided with chlorophyll that the eut end of the branch under a hand-lens appears grass green. In much larger stems, however, and in smaller ones from a less healthy plant no chlorophy 11 , or scarcely any, is to 


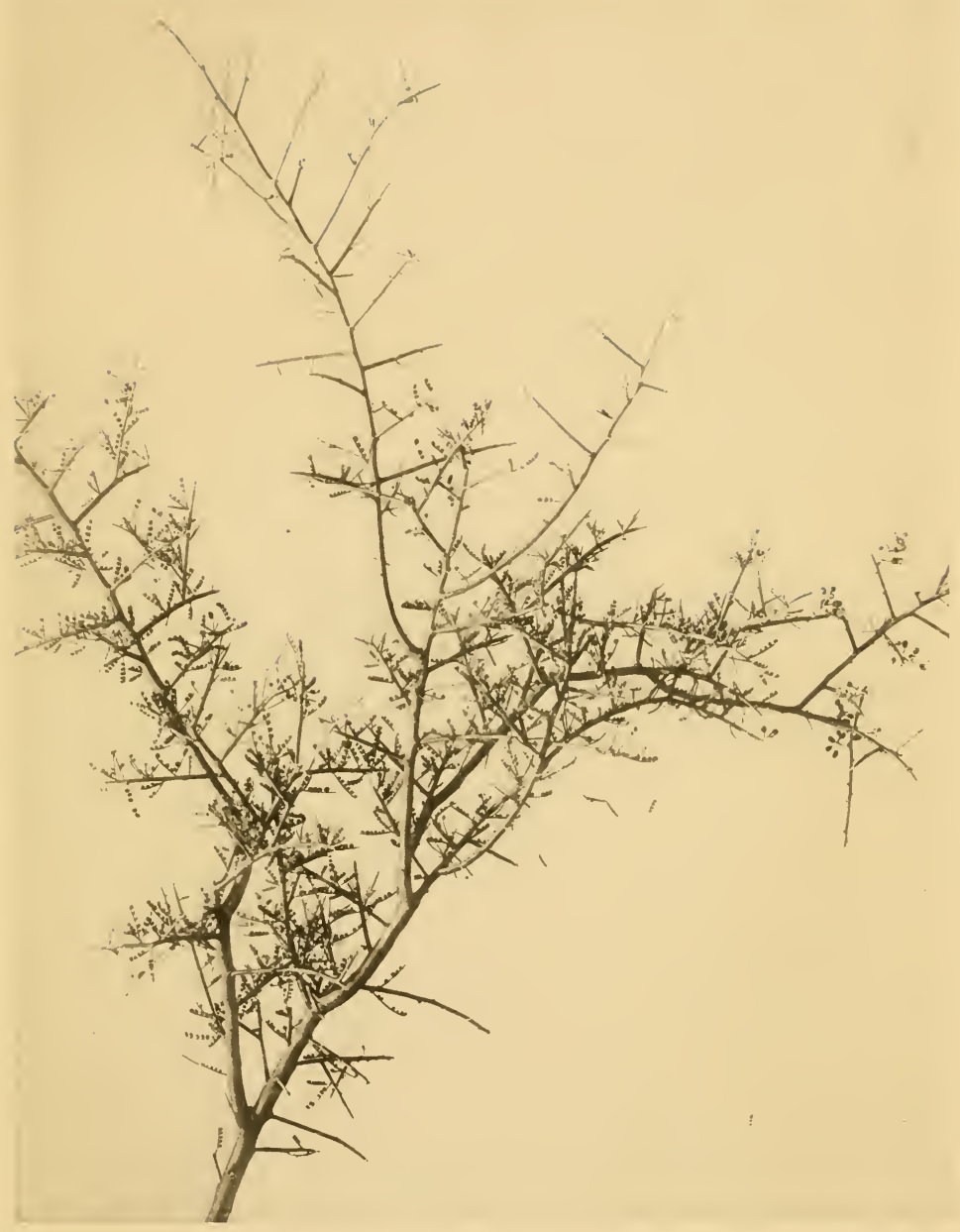

PARKINSONIA MICROPHYLLA. The species from which this branch was taken deciduous; the branches are green and function as leaves. April 25, 1907. 

be found in the wood. The wood parenchyma in the immediate vicinity of the ducts may contain chlorophyll (fig. 10).

As to chlorophyll in the pith, it need only be said that it occurs sparingly in stems $1 \mathrm{~cm}$. in diameter and is not present in the older and larger branches.

The chlorophyll disappears from the stem in a very regular sequence. It leaves the epidermis first, then the pith, then the inner medullary rays; after this the wood parenchyma, then the medullary rays of the cortex and the median band, and finally, when cork is formed, the outer band. That is, with two exceptions, the chlorophyll disappears from the stem in a centrifugal direction. The exceptions were most marked in stem of $P$. torreyana $8 \mathrm{~mm}$. in diameter, in which practically all of the chlorophyll of the pith, as well as of the medullary rays of the wood, had been removed, but the deeply-placed wood parenchyma near the ducts still contained chlorophyll in considerable quantity.

The leading departures from the chlorophyll conditions shared in common by the three species of Parkinsonia are as follows: $P$. aculeata: Branches 7 and $12 \mathrm{~mm}$. in diameter had no chlorophyll in pith or in the inner part of the wood. P. microphylla: A variation due possibly to differences in water relations was observed in branches $1 \mathrm{~cm}$. in diameter. One branch, taken from a tree which was apparently poorly supplied with water, had very little chlorophyll in the wood and none in the pith, while another branch of the same diameter, taken from a tree that had been irrigated at frequent intervals, had the maximum distribution of chlorophyll. $P$. torreyana: As may be implied from a previous statement, this species appears not usually to have so much chlorophyll in its branches as the other ones, but an exception was noted in a stem $2.25 \mathrm{~cm}$. in diameter, in which the chlorophyll was in the epidermis and extended into the stem for a distance of $6 \mathrm{~mm}$. This tree was growing in a particularly favorable location in the wash at the west base of Tumamoc Hill.

The following measurements were made:

\begin{tabular}{|c|c|c|c|c|}
\hline \multirow{2}{*}{ Species. } & \multirow{2}{*}{$\begin{array}{l}\text { Diameter } \\
\text { of branch. }\end{array}$} & \multicolumn{2}{|c|}{ Outer cortical band. } & \multirow{2}{*}{$\begin{array}{l}\text { Penetration } \\
\text { of chloro- } \\
\text { phyll. }\end{array}$} \\
\hline & & Depth. & Width. & \\
\hline P. aculeata $\ldots \ldots \ldots \ldots \ldots$ & $m m$. & $\mu$ & ${ }_{0}^{\mu} 60$ & $m m$. \\
\hline 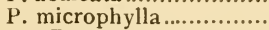 & 3 & 83 & $8_{3}$ & I. 5 \\
\hline Do............................. & I0 & ....... & ....... & 0.5 \\
\hline Do........................... & II. 5 & 144 & 130 & 1.8 \\
\hline Do............................. & 15 & 112 & I 44 & 1.5 \\
\hline Do.............................. & $3^{2} \cdot 5$ & 160 & 234 & 1.6 \\
\hline Do $\ldots \ldots \ldots \ldots \ldots \ldots \ldots \ldots$ & 49 & 130 & 246 & 2 \\
\hline Do................................ & so & 160 & 160 & ....... \\
\hline P. torreyana ......................... & 8 & $6+$ & 144 & ....... \\
\hline 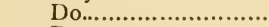 & 10 & 96 & 176 & 5 \\
\hline Do........................... & 12.5 & 96 & 160 & \\
\hline Do.......................... & 22.5 & 96 & 196 & 6 \\
\hline Do.................................. & 30 & 128 & 224 & 0.4 \\
\hline
\end{tabular}




\section{Prosopis velutina. (Figs. 12, 13, and 14.)}

Prosopis velutina is the most characteristic tree of the river-bottoms, where in places it forms extensive forests. It varies in size from a small shrub to a well-formed and shapely tree $15 \mathrm{~m}$. or more high. The difference in size depends mainly on the lack or the abundance of the water-supply. Leares are formed in the spring and are shed in the autumn with a regularity characteristic of deciduous trees of more humid regions.

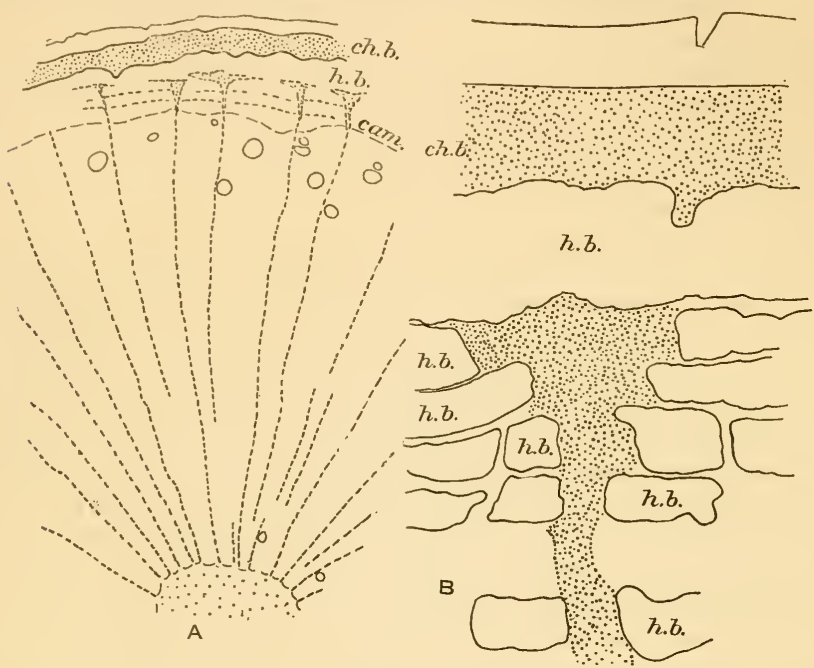

F1G. 12.-Prosopis velutina: $A$, transverse section of stem $4 \mathrm{~mm}$. in diameter, to show distribution of chlorophyll; $B$, segment from cortex of stem $7 \mathrm{~mm}$. in diameter, to show relation of hard bast $(h . b$.) to chlorophyll.

The sections of branches studied were cut at nine separate intervals from $3 \mathrm{~cm}$. to $1.23 \mathrm{~m}$. from the tips, and were from $1.3 \mathrm{~mm}$, to $1.5 \mathrm{~cm}$. in diameter.

In several particulars the distribution of chlorophyll in Prosopis recalls that in Parkinsonia. In the young stem chlorophyll may be found in practically all of the ground-tissue both of cortex and of wood. With increase in size the chlorophyll distribution of the stem becomes greatly restricted and the topography of the chlorophyll apparatus becomes much changed. The general structural relations of the stem will be apparent from the succeeding account of the distribution of the chlorophyll and will not require especial discussion.

The epidermal cells of Prosopis do not contain chlorophyll-in this as well as certain other particulars Prosopis is unlike Parkinsonia. Prosopis 
stems older than one year have in the cortex a varying number of concentrically placed hard-bast rings which are broken at intervals where the medullary rays penetrate the cortex. Between the rings of hard bast is to be found a thin-walled parenchyma. It is the disposal of the hard bast, together with the disposal of this parenchyma, that in stems $4 \mathrm{~cm}$. in diameter and less determines the character of the distribution of chlorophyll in the inner portion of the cortex. A cross-section of a stem $4 \mathrm{~mm}$. in diameter shows the chlorophyll-bearing cells of the cortex arranged in the general form of a net, in which what may be called the warp is the medullary rays and the woof the parenchyma, or that portion of the parenchyma that separates the rings of hard bast. The woof of the texture in young stems occurs along the inner side of the secondary hard-bast rings, but in oider stems, for reasons given below, it occupies practically the entire space between the bast groups.

With increase in size of the stem certain changes occur in the chlorophyll apparatus which are dependent on the dispositon of the other cortical tissues. As the circumference of the stem becomes greater the groups of bast become farther apart, while at the same time, as a result of the radial pressures set up, the rings are approximated nearer and nearer to each other. The most notice able effects of these changes occur naturally in the more peripheral portions of the cortex. The primary medullary rays in

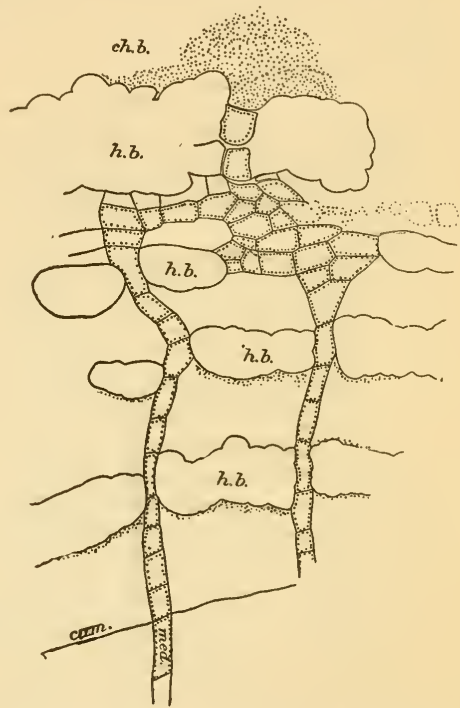

FIG. I2.-Prosopis velutina: Detail from inner portion of cortex of stem, to show structure of distal ends of medullary rays and connection between outer mass of chlorophyll $(c h . b$. ) and the more deeply lying chlorenchyma. h.b., hard bast; $c h$. $b$., cortical chlorophyll band.

young stems extend to the hard-bast ring, and when by the growth of the stem this is broken up and its members are connected by stony tissue the rays extend to the stony tissue of this ring. Secondary hard-bast rings are formed within the primary one, between the segments of which pass the medullary rays. With the growth of the stem the outer groups of secondary bast separate from one another, just as happened with the primary bast groups, and the more peripheral rings become closely pressed together. These general relations not easily described will be apparent from the sketches. 
In the young stem the medullary rays of the cortex are about one cell wide, but as the hard-bast groups separate from each other with the growth of the stem the rays broaden to fill out the resulting gaps until the ends are many cells wide. The most striking effect is associated with the primary rays. They feel the effects of the growth sooner than the other rays and of a consequence the ends of the primary medullary rays are fanshaped and present in cross-section a very striking appearance. From this manner of differentiation and development of tissues the amount of chlorenchyma in the young cortex is much increased.

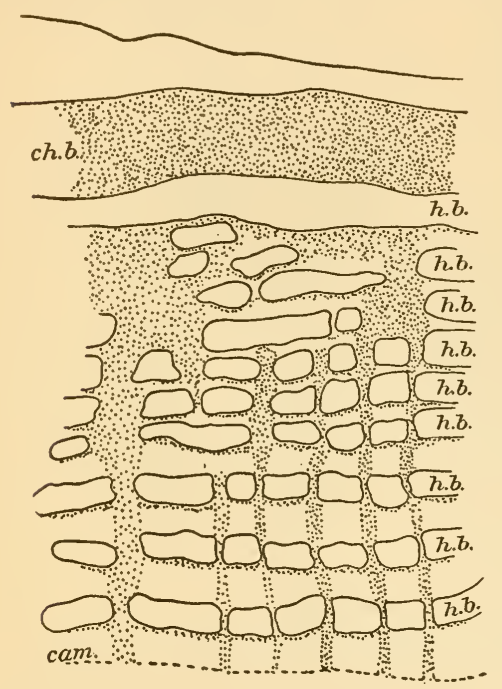

F1G. I4.-Prosopis velutina: Segment of stem $1.5 \mathrm{~cm}$. in diameter, in which is shown arrangement of rings of hard bast and their relation in the chlorophyll apparatus.

Growth of the stem works also to modify the relations of the outer chlorophyll band in a way that may be noted. In a branch $1.3 \mathrm{~mm}$. in diameter an unbroken ring of hard bast separates the chlorophyll band from the inner cortical tissues. In a branch $4.5 \mathrm{~mm}$. in diameter the hard-bast ring becomes broken up into groups, as was described above. The connecting cells at first with thin walls become, finally, stony tissue and contain chlorophyll. As a result the outer band is joined to the medullary rays and practically the entire chlorophyll apparatus is welded into a single tissue. Later, however, the outer band of chlorophyll becomes again separated from the inner chlorenchyma by the further development of the same stony tissue.

As in Parkinsonia, chlorophyll occurs in the medullary rays of the wood, in the parenchyma of the wood, and in the pith. In order of disappearance it leaves the pith and the inner medullary rays first; it lingers behind in the parenchyma surrounding the ducts. The exact time, however, that the chlorophyll leaves the woody cylinder was not learned. In a branch $4 \mathrm{~cm}$. in diameter no chlorophyll was to be seen in the wood, and it did not extend deeper than $0.5 \mathrm{~mm}$. beneath the surface of the stem.

The later history of the chlorophyll apparatus is connected with the formation of bark. This is one of the factors which brings about the changes in appearance of the stem which are characteristic of it at different times during development. 
In the early part of the first year of growth the branch is smooth and of a dark purple color; later in the season it becomes green and is flecked with minute purple or red dots and is somewhat rough to the touch. During the following season and for an undetermined period afterwards it remains green. Finally this is replaced by a gray surface which also is slightly rough and which persists for several years. Branches $8 \mathrm{~cm}$. in diameter may have this appearance. The gray exterior is in turn replaced in old stems by a rough bark black in color.

The color of the youngest stem is due to red and blue pigment in the epidermis, and the texture of the surface to the unbroken cuticle. As the stem becomes older, phellogen arises in the epidermis, which forms primary periderm and primary phelloderm. Ruptures appear in the cuticle, which become pronounced and allow the chlorophyll to be seen through the corky tissue. As the stem becomes larger the amount of cork increases, the amount of phelloderm especially becomes greater, and at length entirely conceals the underlying chlorophyll. This condition lasts a long time and constitutes the third stage, as presented above. Finally, in still older stems a secondary phellogen is organized deeper in the cortex than the chlorophyll band and separates this tissue to its ruin from the remainder of the stem. After the formation of the secondary phellogen the stem does not as a consequence contain more chlorophyll.

The following measurements were taken:

\begin{tabular}{|c|c|c|c|c|}
\hline $\begin{array}{l}\text { Diameter } \\
\text { ot branch. }\end{array}$ & $\begin{array}{l}\text { Distance } \\
\text { from tip. }\end{array}$ & $\begin{array}{l}\text { Depth of } \\
\text { chlorophyll }\end{array}$ & $\begin{array}{l}\text { Width of } \\
\text { chlorophyll } \\
\text { band. }\end{array}$ & $\begin{array}{l}\text { Depth of } \\
\text { chlorophyll } \\
\text { band. }\end{array}$ \\
\hline$m m$. & $\mathrm{cm}$. & $m m$. & $\mu$ & $\mu$ \\
\hline I. 3 & 3 & 0.65 & 32 & 32 \\
\hline & $\begin{array}{l}18 \\
33\end{array}$ & 0.80 & 32 & 48 \\
\hline 3.3 & 48 & $\begin{array}{l}1.65 \\
\end{array}$ & 64 & $\begin{array}{l}04 \\
48\end{array}$ \\
\hline 4.5 & 63 & 2.25 & 64 & 48 \\
\hline 5 & 78 & $2 \cdot 3^{2}$ & 64 & 48 \\
\hline 7 & 93 & $3 \cdot 30$ & 64 & $4^{8}$ \\
\hline 9 & 108 & $3 \cdot 30$ & 106 & 32 \\
\hline 15 & 123 & ....... & 100 & 48 \\
\hline
\end{tabular}

\section{SALIX NIGRA.}

Salix occurs in some abundance along the banks of the bed of the Santa Cruz River. Some of the trees may attain a height of $15 \mathrm{~m}$. or more.

A section of a branch $3.5 \mathrm{~mm}$. in diameter $30 \mathrm{~cm}$. from the tip shows the following general relations of the tissues: Beginning with the periphery there is (1) a protective portion abont four cells deep, which does not contain coloring matter, and a protective portion beneath this about two cells in thickness that is pigmented; (2) a parenchymatous tissue which is chlorophyllaceous; (3) groups of hard bast and inner ground-tissue and cambium; and (4) finally, the woody cylinder. 
The chlorophyll occurs in the parenchyma, which is immediately within the many-celled protective layer but not in a well-defined band, in the medullary rays of cortex and of wood, and in the pith. As is usually the case with growth of the stem, the distribution of the chlorophyll is changed and it becomes much reduced in amount. In a branch $8.5 \mathrm{~mm}$. in diameter and $90 \mathrm{~cm}$. from the tip the chlorophyll was confined to the outer portions of the medullary rays and to the eortex; and in a branch $1.3 \mathrm{~cm}$. in diameter and $150 \mathrm{~cm}$. from the tip it had left the woody eylinder entirely and was to be fottnd only in the subepidermal chlorophyll band. The fate of the ehlorophyll band was not learned.

\section{Sambucus mexicana.}

Sambucus occurs as scattered individuals by roadsides on the river-bottoms. It forms a small tree from 5 to $8 \mathrm{~m}$. high, with a main stem 15 to $20 \mathrm{~cm}$. in diameter. The tree which was selected for study is growing by the Hospital Road east of the Laboratory domain. It is about $6 \mathrm{~m}$. high and has a polled appearance, as if most of the shoots were second growth.

The topography of the chlorophyll apparatus presents no unusual characters. In the youngest portions of the branch, $2.5 \mathrm{~mm}$. in diameter and $0.5 \mathrm{~cm}$. from the tip, all of the ground-tissue is chlorophyll-bearing. That is to say, chlorophyll is to be found from the epidermis to the center of the extensive pith and in all tissues except those already differentiated. There appears to be no distinct cortical band. The chlorenchyma is made up of spongy tissue, which for the most part has very thin walls and prominent intercellular spaces. No change in the distribution of the chlorophyll is to be noted until the stem is about $4.5 \mathrm{~mm}$. in diameter, when none may be found in the pith and but little in the inner portion of the cortex outside of the medullary rays. It occurs in the medullary rays of the wood.

When chlorophyll wholly left the stem was not determined. In a branch $8 \mathrm{~mm}$. in diameter and $25 \mathrm{~cm}$. from the tip, chlorophyll was found in the parenchyma of the primary cortex immediately within the mechanical tissue and nowhere else. In another branch $1.6 \mathrm{~cm}$. in diameter and at a point $1.23 \mathrm{~m}$. from the tip the distribution was found to be quite the same.

The youngest portions of the stem are frequently green, $i . e$. , there is no protective covering for the chlorophyll. The second node is often purple from a red-blue pigment in the subepidermal cells. In the next older node there may in addition be a heavy covering of trichomes. Also, the corkcambium is laid down early in the development of the branch and takes its origin in the subepidermal cells, so that it happens that some sort of protection against excessive illumination or excessive transpiration, either the leafy covering of the stem, pigmented cells, a hairy coating of the epidermis, or cork is given the chlorenchyma during its entire existence. 


\section{ZIZYPHUS PARRYI. (Plate 5 and fig. 15.)}

Zizyphus occurs sparingly on the river-bottoms or elsewhere where the water conditions are fairly good. It is a grayish-colored (due to hairy covering) spiny shrub from 1.5 to $3 \mathrm{~m}$. high and bears during favorable seasons a considerable leaf-surface. As is the case with the most of the desert perennials, the leaves fall away with the advent of dry conditions and leave the shrub bristling with spines in a condition very much like the ordinary condition of Keberlinia emoryi.

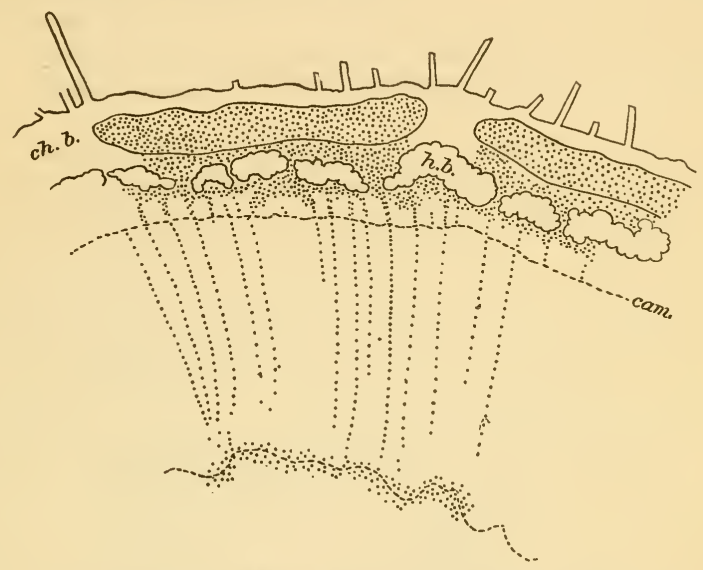

F1G. 15.-Zizyphus parryi: Section of stem $3 \mathrm{~mm}$. in diameter, to show distribution of chlorophyll. ch. $b$, cortical chlorophyll band; $h . b$., hard bast; cam., cambium.

The young stem of Zizyphus shows the customary divisions into cortex, wood, and pith, of which the latter is especially abundant. The main divisions of the cortex are the epidermis with its rather heavy cuticle, a chlorophyll band beneath the epidermis, a hard-bast ring which is discontinuous, and the ground tissue between it and the cambium.

The distribution of the chlorophyll is very much as in other plants. The outer cortical parenchyma, most of the inner cortical parenchyma, the medullary rays, and the outer pith-cells contain chlorophyll. The outer chlorophyll band, which is interrupted at frequent and fairly regular intervals by masses of collenchyma, has a palisade structure, at least in the outer part, of short cells very like the cells in the leaf. The inner chlorenchyma cells are cuboid. The parenchyma and the collenchyma between the chlorophyll band and the groups of hard bast deeper in the cortex contain chlorophyll. The medullary rays of the cortex are also chlorophyllbearing. The rays either end in the groups of hard bast or pass outward 
between them and join the broad band of chlorophyll. Chlorophyll-bearing tissue on the inner face of the ring of hard bast connects the medullary rays. So that there are three rings of chlorenchyma in the cortex, namely, the chlorophyll band and two inner rings separated by hard bast. The medullary rays of the wood and of the pith in a stem $3 \mathrm{~mm}$. in diameter contain small amounts of chlorophyll.

With increased diameter certain changes in the distribution of the chlorophyll occur which should be noted. As usual, these modifications are most marked in the cortex. With lateral stretching, which accompanies the growth of the stem, the groups of hard bast become farther and farther apart and the intervening spaces become filled with a chlorophyll-bearing tissue, so that the relative and actual amount of chlorenchyma is much increased.

In stems $1.4 \mathrm{~cm}$. in diameter the formation of cork has begun. The phellogen appears to take its origin in the epidermis and shows little indication of activity. Only a small amount of periderm was observed and almost no phelloderm. The periderm in the larger branches is colored a deep red and is broken through at intervals by lenticels. No chlorophyll is to be found in wood or pith, although in a stem $1.55 \mathrm{~cm}$. in diameter and $1.6 \mathrm{~m}$. from the tip the cortical chlorophyll band was still to be seen. When it disappeared from the stem, if ever, was not learned.

The following measurements were made:

\begin{tabular}{|c|c|c|c|c|}
\hline $\begin{array}{l}\text { Diameter } \\
\text { of branch. }\end{array}$ & $\begin{array}{l}\text { Distance } \\
\text { from tip. }\end{array}$ & $\begin{array}{l}\text { Width of } \\
\text { cortex. }\end{array}$ & $\begin{array}{l}\text { Width of } \\
\text { chlorophyll } \\
\text { band. }\end{array}$ & $\begin{array}{l}\text { Depth of } \\
\text { ehlurophyll } \\
\text { band. }\end{array}$ \\
\hline $\mathrm{mm}$. & $\mathrm{cm}$. & $\mu$ & $\mu$ & $\mu$ \\
\hline 3 & 5 & 192 & 57.6 & 19.2 \\
\hline $3 \cdot 5$ & 20 & 256 & 76.8 & 19.2 \\
\hline $4 \cdot 5$ & 35 & 262.4 & 89.6 & 19.2 \\
\hline 6 & 50 & 381.8 & So & 22.4 \\
\hline 8 & 80 & $39^{8} .4$ & 73.6 & 22.4 \\
\hline 14 & 110 & 664 & 64 & 41.6 \\
\hline 14.5 & 140 & 664 & 64 & $3^{2}$ \\
\hline 15.5 & 160 & 747 & 41.6 & 35.2 \\
\hline
\end{tabular}




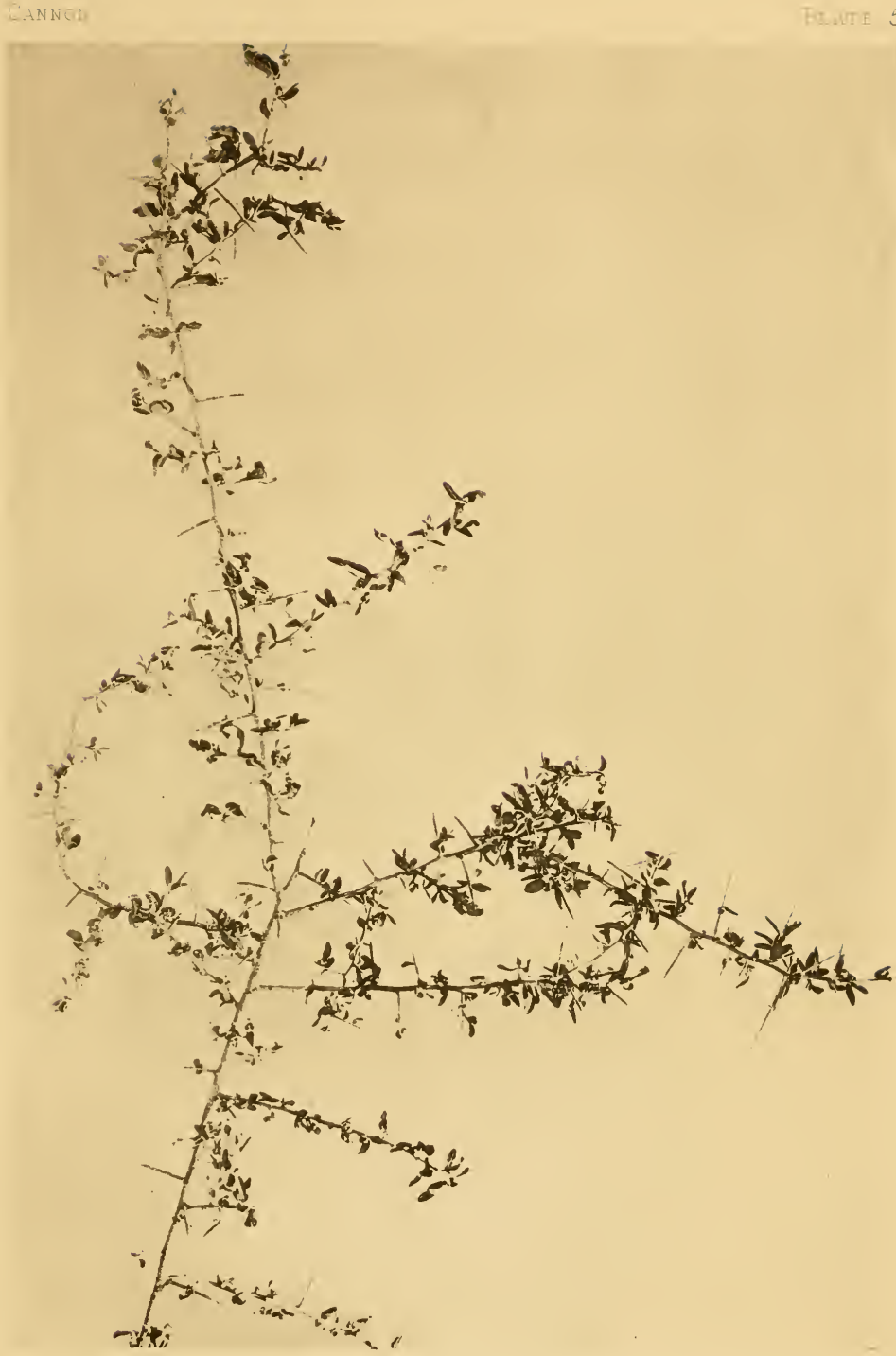

ZIZYPHUS PARRYI. Branch from a plant which is situated by the St. Mary's Road near the laboratory domain. Zizyphus is a plant with the deciduous habit. April 25, 1907. 



\section{GENERAL DISCUSSION AND RESULTS.}

\section{MORPHOLOGY OF THE CHLOROPHYLL-BEARING TISSUES.}

Although different in details, the general arrangement of the chlorophyll apparatus in the stems of desert perennials has in many respects a close similarity, for which reason the type arrangement can be presented by describing an ideal stem.

The ideal branch will have a diameter of $5 \mathrm{~mm}$., with the following structural divisions: (1) an epidermis with a relatively heavy cuticle; (2) a hypodermal tissue about three cells in thickness; (3) an outer cortical chlorophyll band, which is somewhat wider than the hypoderm and which lies immediately beneath it; (4) a hard-bast ring; (5) the inner portion of the cortex, in which are the distal ends of the medullary rays, perhaps secondary hard bast and undifferentiated ground-tissue; (6) the woody cylinder and the pith. Medullary rays are prominent and wood parenchyma is present in considerable amount.

Such being the general structural relations of the stem, the chlorophyll is distributed as follows: The leading chlorophyll-bearing tissue is the subepidermal band, and this is true not only because it is the most extensive of the stem, but also, as will be shown below, because it retains chlorophyll the longest of any of the tissues. Moreover, it is rarely changed into any other kind of tissue, but persists as chlorenchyma until, as a general thing, it is cut off by the formation of cork.

The medullary rays, both of the wood and of the cortex, contain chlorophyll. The distal ends of the medullary rays extend into the cortex and between the groups of hard bast and abut on the inner face of the chlorophyll band, by which circumstance the chlorenchyma of the stem is for the most part bound into one continuous system. In addition to the chlorophyll band and the distal ends of the medullary rays, there is in the cortex another kind of chlorenchyma, namely, the ground-tissue, that lies immediately within the hard-bast groups. In the woody cylinder, in addition to the medullary rays, the wood parenchyma also may contain chlorophyll. This is true especially of those cells that are placed near the ducts. Lastly, the pith may be chlorophyllaceous. Generally speaking, therefore, with the exception of certain embryonic tissues in the cortex, all of the parenchyma of the stem may contain chlorophyll.

As the stem increases in diameter, certain changes in these tissues, as a whole, and in those which are chlorophyll-bearing, are seen to take place, some of which should be noted. These may be outlined as (1) the gradual disappearance of the chlorophyll and (2) as modifications in the topography of the chlorophyll apparatus, as above sketched.

In the usual condition there is a certain order in the recession of chlorophyll in the stem. This is as follows: It disappears first from the pith; 
then from the medullary rays of the wood, beginning in the inmost portions; then from the wood parenchyma; after this, from the medullary rays of the cortex; and, lastly, from the chlorophyll band, or, more usually, the band itself is obliterated. In the exceptional event of chlorophyll in the epidermis of the younger stem, as in Parkinsonia, this may leave the stem before any other tissue is deprived of its chlorophyll. Generally speaking, however, with the exception of the wood parenchyma, the chlorophyll of the stem disappears in a centrifugal fashion. Possibly the exception is due to some favoring condition, as the proximity of better air-supply, or more water, or the light may be condensed by the water-content, so that a portion of the contiguous parenchyma may have better light relations than that in the medullary rays.

The chlorophyll band remains active until its organic connection with the inner living portions of the cortex is severed by the formation of cork, or until destroyed by pressure occasioned by growth of the stem. In some forms, as Cereus and Parkinsonia, as a rule, it is never destroyed during the life of the plant, but persists and gives the color characteristic of each.

SPECIAL STRUCTURAL FEATURES.

We may turn now from a review of what may be called the general condition of the stem as regards the distribution of chlorophyll and take note of phases of the distribution and other characters of the chlorophyll-bearing tissues not shared by all of the plants examined.

Attention may first be called to a curious modification of the chlorophyll band which frequently accompanies increase in diameter of the stem. This is associated with the formation of cork. The chlorophyll band, properly so-called, is an integral portion of the primary cortex; in old stems, however, the outer part of the band may be morphologically secondary cortex. This circumstance occurs in the following manner: When cork is formed, it is likely to take its origin in cells exterior to the chlorophyll band and very close to it. By the activity of the phellogen periderm is organized without and phelloderm within in the usual fashion and in the cells constituting the phelloderm chlorophyll may be found. Consequently it happens that in older stems of certain plants, as in Celtis pallida, fig. 3, the outer portion of the chlorophyll band, in addition to being of different origin, may be more recently organized than the inner portion. There appears to be a limit to the thickness of the chlorophyll band brought about by this means, however, as the portion of the band which is of secondary origin has never been seen to be more extensive than the primitive part.

Another point which has to do with the structure of the chlorophyll band relates to the similarity in some cases and the dissimilarity in others of the structure of the band in the stems and the structure of the chlorenchyma of the leaves of the same plant. In all plants studied palisade tissue of some sort was found in the leaves, but in part only of the plants was the 
chlorophyll band of the stems also palisade--it was frequently spongy tissue. $^{*}$ There is a relation between the structure of the chlorenchyma of the stem and the foliar habit of the plant which holds in all well-marked cases and which comparative studies on the forms and their relatives may show to be valid in cases now not so clear. The relation may be stated thus: In perennials with no leaves, or with rudimentary leaves, the chlorophyll band of the cortex is structurally palisade tissue. On the other hand, perennials with relatively large leaves, or a large leaf-surface, have chlorophyll bands of spongy tissue. The following-named plants either have no leaves at any time of the year (in mature stage) or the leaves are clearly of a rudimentary nature and the chlorenchyma of the cortex is uniformly palisade: Aster spinosus, Baccharis emoryi, Ephedra antisyphilitica, Lober. linia spinosa; although different in certain regards the outer part of the chlorenchyma of Cereus may also be said to be palisade. On the other hand, the following plants have a pronounced leaf-surface and the chlorenchyma is spongy tissue: Condalia spathulaca, Covillea tridentata, Fouquicria splendens, Parkinsonia aculeata, P. torreyana, Salix nigra, Sambucus mexicana. The leaves of Kramcria canescens should probably be considered rudimentary, although of fairly large size; during the driest seasons the plant is leafless. The chlorenchyma of the stem is palisade. Zizyphus parryi has a large leaf-surface and the leaves are not unlike those of Fonquieria; like Krameria, the leaves are usually absent during dry times. The chlorophyll band is palisade. Parkinsonia microphylla, as the specific name indicates, has very small leaves, so small that their presence is hardly noted, and yet the chlorenchyma of the stem is of spongy tissue. It should be said also that the leaves of $P$. microphylla, as well as those of the most leafy forms, fall away with the advent of dry seasons.

Whatever may be the significance of this variation in structure of chlorenchyma of stems of perennials, there appears to be a fairly uniform relation between it and the charaeter of the tissues exterior to the band. The exceptions to this relation are at least no more striking than the exceptions to the relation of structure and leaf-habit given above. The relations have to do especially with the depth of the chlorophyll band, the presence or the absence of pigment in the exterior tissues, and perhaps also with the presence or absence of trichomes.

As a rule, the depth of the chlorophyll band may vary with the age of the stem; however, in young stems, $e . g$., those about $1 \mathrm{~cm}$. in diameter, there is much constancy in this regard. Aster spinosus, Baccharis emoryi, and Krameria canescens, all of which must be considered plants with a reduced transpiring surface, have the following depths of the chlorophyll band: $19.2 \mu, 16 \mu, 18.8 \mu$, respectively. These forms have palisade chlor-

*The leaves of Opuntia versicolor, and perhaps of other opuntias, do not appear to have palisade tissue, although palisade-like tissue is to be found in the permanent parts, namely, the stems. Compare fig. 14, Biological Relations of Certain Cacti, W. A. Cannon, American Naturalist, 1906, $40: 27$. 
enchyma in the stem. With its extremely thick cuticle, $80 \mu$, Kaberlinia is a marked exception to this condition. Contrast the depth of the band as given for these species with that of the stems of Celtis pallida, Covillea tridentata, Parkinsonia-representing the leafy class of parennials. The figures are $96 \mu, 48 \mu$, and $83 \mu$, respectively. All of these forms have spongy chlorenchyma in the stem.

There is also fair consonanee between the kind of ehlorenchyma and the kind of tissue exterior to it. In Aster, Baccharis, Krameria, Kaberlinia, Cercus-plants with a reduced leaf-surface or with no leaves - the chlorophyll band extends to the epidermis. Such is the condition to be met, not alone in young, but also in old stems of these plants, which, however, is not the final condition in most of them. In the type of plants with larger leaves, or larger leaf-surface, on the other hand, there is frequently when young, and always when old, some sort of tissue, in addition to the epidermis, which serves as a covering to the chlorophyll band. This may be hypodermal tissue, cork in most plants, or in Olneya a curious proliferation of the epidermal eells in the young branches by which a many-layered epidermis is organized. It will be recalled that in the former class of perennials the chlorenchyma is palisade and in the latter spongy tissue.

In yet another structural characteristic the two classes of plants are distinguished. With certain exeeptions plants with rudimentary leaves or none have no pigment in the epidermis, $i . e$., the parts exterior to the chlorophyll band are colorless. But in Celtis, Condalia, Olneya, and Prosopis all forms possessing a pronounced leaf-surface, either the epidermis or the hypoderm, or again the periderm, is provided with a pigment which is usually of a dark-red color. In these forms the ehlorenchyma is of spongy tissue. An exception to this is found in Parkinsonia, which has no pigmented tissues exterior to the chlorophyll band.

The coincidences which have been repeatedly observed of spongy chlorenchyma and pigmented exterior tissues lead to the belief that the relation between the two is something more than a chance association. This is strengthened by the further observation that in palisade chlorenchyma no such exterior pigmented cells are usually to be found.

Although no hard and fast rule can be given, it appears that perennials which have a reduced leaf-surface present the following characteristics regarding the chlorophyll band of the stem: Its structure is wholly or at least in part palisade; it usually lies close to the surface, and the tissues exterior to it usually do not contain pigment. While, on the other hand, perennials with a pronounced leaf-surface possess a chlorophyll band of spongy tissue, there is usually some kind of tissue in addition to the epidermis between it and the surface, and the exterior tissue usually contains pigment. 


\section{PENETRATION OF THE CHLOROPHYLL.}

The greatest depth at which chlorophyll was found beneath the surface of the plants varied from $0.38 \mathrm{~mm}$. in Lieberlinia spinosa to $6.6 \mathrm{~mm}$. in Cereus giganteus. In ordinary leaves chlorophy 11 occurs from $0.04 \mathrm{~mm}$. to $0.35 \mathrm{~mm}$. from the surface. As contrasted with the depth of chlorophyll in leaves, that in the stem is, therefore, from about 9 to 165 , or 0.5 to 18.8 times more distant. In these desert plants, of a consequence, there are very umusual conditions to which the chlorophyll of the stems may be subjected and under which photosynthesis may be carried on. The most deeply placed chlorophy11 probably has the minimum amount of light, or the minimum degree of aeration, or the least amounts both of air and of light. Adequate water-supply as well as suitable temperature, more surely the latter, ${ }^{*}$ are presupposed to exist.

As is well known, chloroplastids of certain plants may exereise their function of carbon assimilation under cxceedingly feeble illumination. Pfeffer (Physiology of Plants, Eng. ed., vol. 1, p. 340) states that photosynthesis may oceur at an illumination 1/600000 the intensity of sunlight. It is not surprising, in view of this, in a region where light is so intense as in the desert, that we find chlorophyll over $0.5 \mathrm{~cm}$. beneath the surface (in extreme instances probably much deeper than this).

The light tonus probably plays an important rôle, as indicated by the range of the position of chlorophyll in the stem. This condition is well known in plants inhabiting more moist regions. Chloroplasts of many plants become pale and discolored after a few days in darkness. The paling of grass and of low herbaceous plants in weak light which obtains during a long wet season are familiar examples of the dependence of the chloroplastids of such forms on a constant and considerable supply of light. On the other hand, plants belonging to the Cactaceæ and Coniferæ, as well as Elodea, Chara, etc., are more resistant and may remain green for a month or more in darkness. But the fact that at a depth of $6.6 \mathrm{~mm}$. the chloroplastids of Cereus are green in old stems is indication not of survival but of their being functional at the moment. It is not known what the maximum light stimulus may be that the chloroplastids of Cereus may endure without injury, but Pfeffer states that chloroplastids of Elodea can be exposed to light more intense than 60 times concentrated sunlight without injury. If a comparison of the life conditions of Elodea with that of the desert forms is permissible, we might expect the chloroplastids of Cereus and of other desert types to be exceedingly resistant to light.

The considerable extent of the chlorophyll apparatus in the desert plants emphasizes another condition which is probably not present in leaves, or if so, to a limited extent only, namely, what may be termed the light stress which the protoplast of the desert plant experiences. The outer chloro- 
plastids are subject to an unknown but high degree of insolation; to which the innermost ones are subject to an unknown but exceedingly small degree. Thus there is experienced at the same moment a very wide range in the intensity of the light stimulus. What the effect on the morphology of the chlorenchyma, especially, of this light stress in sueh a plant as Cereus, in which the chlorophyll-bearing tissues endure throughout the life of the plant, perhaps unchanged, may be, has not been inquired into, but probably it is a very important factor to be reckoned with and one that must be taken into account in studies on this general subject.

The relation of the deeply seated chloroplastids in the stem of such plants as Cercus or Parkinsonia to air is very different from such relation in leaves, where the character of the structure insures abundant aeration. To a relatively long distance from the source of supply of oxygen and carbon dioxicle and small intercellular spaces of the typical xerophyte, is added immobility of stems, so that gaseous exchange between the external atmosphere and that inside the plant, as well as between different portions of the plant, is not aided by various bendings and movements characteristic of leaves. This may result in a condition in which unusually small amounts of air reach the deeper tissues, so for this reason photosynthesis is precluded. Indeed, the manner of recession of the chlorophyll from the stem suggests that poor aeration rather than the lack of sufficient light may be an important factor in limiting the depth at which chlorophyll may be functional. It will be recalled that in Celtis pallida, as well as in other forms, the wood parenchyma which surrounds or is most closely related to the large ducts retains chlorophyll after it has disappeared from other portions of the woody cylinder as far removed from the surface or even considerably nearer the surface.

Penetration of the chlorophyll.

\begin{tabular}{|c|c|c|}
\hline species. & $\begin{array}{l}\text { Diameter } \\
\text { of branch. }\end{array}$ & $\begin{array}{l}\text { Depth of } \\
\text { ehlorophyll }\end{array}$ \\
\hline Celtis pallida. & $\min _{8}$ & $m m$. \\
\hline 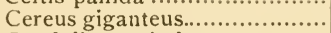 & $(?)$ & $\begin{array}{l}4 \\
6.6\end{array}$ \\
\hline Condalia spathulaca............... & 1.5 & 0.75 \\
\hline Covillea tridentata................. & 3 & 1.5 \\
\hline Fouquieria splendens........... & 30 & 0.9 \\
\hline Kœberlinia spinosa......... & $3 \cdot 5$ & $0.3^{8}$ \\
\hline Krameria canescens............ & 2.5 & 1.25 \\
\hline 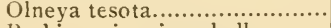 & $5 \cdot 5$ & 2.75 \\
\hline Parkinsonia microphylla.......... & 11 & $5 \cdot 5$ \\
\hline Prosop & $\begin{array}{r}22 \cdot 5 \\
3 \cdot 3\end{array}$ & $\begin{array}{l}6 \\
1.65\end{array}$ \\
\hline Zizyphus emoryi......... & & 4 \\
\hline
\end{tabular}

Pfeffer states (loc. cit., p. 329) that enough carbon dioxide may be taken 11) by the roots, when transpiration is active, to prevent the more deeply seated chloroplastids at the base of the stem from losing the power of assim- 
ilating earbon dioxide when exposed to light for long periods in an atmosphere free from this gas. In Cereus, however, the main source of the gas is probably through the stomata, although, as in Celtis and other plants, the roots may be of importance as organs of aeration as well.

The table on the preceding page presents the greatest observed depths to which chlorophyll penetrates and remains green in the stems of perennials. Considerable care was exereised in selecting material and the estimates in each instance are probably conservative.

\section{IMPORTANCE OF CHLOROPHYLI, BAND.}

As has been already diseussed, the leading chlorophyll-bearing tissue in the stem is the subepidermal chlorenchyma, which in this paper has been designated the ehlorophyll band. This also is the most enduring ehlorophyll tissue of the stem. It constitutes practically the entire carbon assimilative apparatus in plants with reduced transpiring surface-a very important part of the apparatus in deciduous plants-as it does the entire apparatus, or nearly so, in the leafless forms. In Baccharis, Cerens, Fonquieria, Koberlinia, Krameria, Parkinsonia, and Zizyphus it exists throughout the life of the plant; in markedly leafy plants its importance is less, perhaps, but still that it is of great moment in their economy ean not be doubted. It is least important in the evergreen forms, as Celtis pallida and Condalia spathulaca.

The ehlorophyll band has been identified in the following plants at the several distances given from the tip, which are not supposed to represent the maximum distance in any ease, but may do so: Celtis, $178 \mathrm{~cm}$; Condalia, $95 \mathrm{~cm}$.; Covillea, $95 \mathrm{~cm}$.; Franseria, $15 \mathrm{~cm}$.; Olneva, $120 \mathrm{~cm}$.; Prosopis, $123 \mathrm{~cm}$. The relative importance of the band appears more clearly, perhaps, when its volume in several plants is compared. In order to institute the comparison the diameter of stem nearest $1 \mathrm{~cm}$. was taken, and the measurement of the chlorophyll band applied directly to an ideal stem $100 \mathrm{~cm}$. in length and $1 \mathrm{~cm}$. in diameter. In this manner Celtis, with a ehlorophyll band $0.025 \mathrm{~mm}$. wide, would have a volume of $0.098 \mathrm{~cm}$. in a stem $100 \mathrm{~cm}$. in length; Kaberlinia, 0.415; Parkinsonia microphylla, 0.477; Prosopis, 0.578. The ratios are, approximately, Celtis, 1; Koberlinia, 4.1; Parkinsonia, 4.7; Prosopis, 5.7. Of these plants it will be noted that Koberlinia and Parkinsonia rely mainly or wholly on the chlorophyll band for their carbon assimilation all of the year and Prosopis a part of the year, while Celtis, which is evergreen, but nevertheless has considerable chlorophyll in its stem, depends mainly on the extensive leaf-surface. With Prosopis should be classed Olneya; and with Celtis should be classed Covillea and Condalia, whose evergreen habit makes the chlorophyll in the stem of ess importance in the assimilative processes. 
Measurements on the chlorophyll band.

\begin{tabular}{|c|c|c|c|}
\hline species. & $\begin{array}{l}\text { Diameter } \\
\text { of branch. }\end{array}$ & $\begin{array}{l}\text { Width of } \\
\text { ehlorophyil } \\
\text { band. }\end{array}$ & $\begin{array}{l}\text { Depth of } \\
\text { chlorophy } \\
\text { band. }\end{array}$ \\
\hline & $m m$. & $\mu$ & $\mu$ \\
\hline 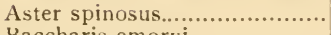 & 2 & $\cdots \cdots$ & 19.2 \\
\hline Baccharis emoryi................... & 1.5 & & 16 \\
\hline Celtis pallida......................... & $3 \cdot 5$ & 25.6 & $9^{6}$ \\
\hline Do.................................... & & 25.6 & 108.8 \\
\hline Cereus giganteus..................... & ..... & ....... & 581 \\
\hline Condalia spathulaca............ & 2 & 32 & so \\
\hline 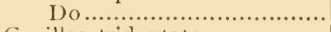 & 12 & so & 19.2 \\
\hline Covillea tridentata .................. & 3 & 64 & $4^{8}$ \\
\hline 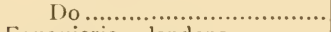 & 95 & 64 & So \\
\hline Fouquieria splendens............... & 5 & $\ldots \ldots$ & $49 S$ \\
\hline 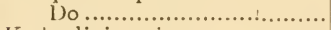 & 30 & ...... & 1162 \\
\hline Koberlinia spinosa .................. & 3.5 & 144 & So \\
\hline Do................................. & 8 & 112 & 64 \\
\hline Krameria canescens................. & 2 & $S_{3.2}$ & 18.8 \\
\hline Do .............................. & 2.5 & 60.8 & 32 \\
\hline Olneya tesota........................... & 1.5 & 48 & 38.4 \\
\hline Do & 11.5 & 160 & 64 \\
\hline Parkinsonia microphylla.......... & 3 & $8_{3}$ & 83 \\
\hline 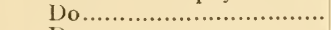 & 11.5 & 130 & $1+4$ \\
\hline 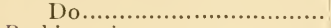 & 49 & 246 & 130 \\
\hline Parkinsonia torreyana.............. & $\mathrm{s}$ & 144 & 64 \\
\hline 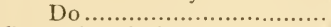 & 30 & 224 & 128 \\
\hline Prosopis velutina......................... & 1. 6 & 32 & 48 \\
\hline 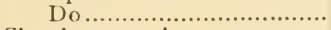 & 9 & 160 & 32 \\
\hline Zizyphus parryi ..................... & 3 & $57 \cdot 6$ & 19.2 \\
\hline 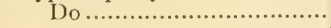 & 14 & 64 & 41.6 \\
\hline
\end{tabular}

PERSISTENCE OF CHLOROPHYLL IN THE WOODY CYLINDER.

Chlorophyll in the woody cylinder is a striking characteristic of young Parkinsonia and Prosopis branches especially, and is found in nearly all of the other desert perennials. Compared to the chlorophyll of the cortex, however, it is likely of little profit to the plant, for the reason that it disappears early from the stem. How long it persists was not learned in any case, since the plants studied did not exhibit annual rings, or in any other way give a cluc as to the rapidity of growth.

The subjoined table gires the character of the branch at a time when the ehlorophyll for the most part had already left the woody eylinder. The measurements were made on the disappearance of chlorophyll.

\begin{tabular}{|c|c|c|c|}
\hline species. & $\begin{array}{l}\text { Diameter } \\
\text { of braneh. }\end{array}$ & $\begin{array}{l}\text { Distance } \\
\text { from tip. }\end{array}$ & Remarks. \\
\hline 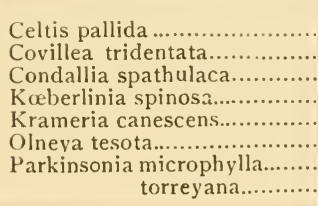 & $\begin{array}{l}m m . \\
10 \\
7 \cdot 5 \\
7 \cdot 5 \\
15 \\
3 \cdot 5 \\
2 \\
15 \\
22.5\end{array}$ & $\begin{array}{r}\mathrm{cm} . \\
\mathrm{I}+4 \\
65 \\
35 \\
60 \\
40 \\
120 \\
\ldots \ldots \\
\ldots \ldots\end{array}$ & $\begin{array}{l}\text { No chlorophyll in wood or pith. } \\
\text { Do. } \\
\text { Do. } \\
\text { Sparingly present in wood and pith } \\
\text { No chlorophyll in woody cylinder. } \\
\text { Do. } \\
\text { Do. } \\
\text { Sparingly present in wood and pith }\end{array}$ \\
\hline
\end{tabular}




\section{SUMMARY.}

The leading results of this study may be summarized as follows:

1. Young stems of desert perennials contain chlorophyll in most of the parenchyma, both of cortex and of woody cylinder. The most important chlorophyll-bearing tissue appears in transverse sections of the stem as a band in the outer part of the cortex.

2. The epidermis of branches of Parkinsonia $1 \mathrm{~cm}$. in diameter may contain chlorophyll.

3. Chlorophyll is present in the phelloderm of the following species: Celtis pallida, Condalia spathulaca, Olneya tesota.

4. There is no chlorophyll in the woody cylinder of Aster spinosus or Baccharis emoryi.

5. The woody cylinder in young stems of Ephedra antisyphilitica and of Olneya tesota do not contain chlorophyll; in older stems the woody cylinder of both is chlorophyllaceous.

6. The chlorophyll band in the stems of Cereus, Fouquieria, Krameria, Parkinsonia, and probably also in Zizyphus, persists throughout the life of the member bearing it. In most plants it is ultimately cut off through the formation of cork.

7. As regards foliar habits the plants studied may be classified into two groups, which, however, are not always well marked. In one class leaves are either rudimentary or wanting; in the other, leaves are present at least during the favorable scasons, $i$. $e$, when the water-supply is adequate to their needs.

8. The differences in leaf-covering are accompanied by fairly consistent morphological differences, as follows: The plants with reduced leaf-surface, or with no leaves, have palisade chlorenchyma in the cortex; the chlorophyll band, at least in young stems, lies near the surface; the tissues exterior to the band in young and generally in old leaves do not exhibit protective devices. Plants with a more pronouneed leaf-surface, on the other hand, have a spongy chlorenchyma in the cortex; it is ustually more deeply placed; and the exterior tissue usually has some protective arrangements, as pigmented cells or a hairy covering.

9. The greatest depth at which functional chlorophyll was found ranged from $0.38 \mathrm{~mm}$. in Keberlinia spinosa to $6.6 \mathrm{~mm}$. in Cereus giganteus. This is from 0.5 to 165 times deeper than the greatest depth of chlorophyll in ordinary leaves.

10. The depth of penetration is probably limited by the air-supply rather than the supply of light.

11. The chlorophyll band of the stem constitutes practically the sole engine for carbon assimilation in Aster spinosus, Baccharis emoryi, Cereus giganteus, Koberlinia spinosa, Krameria canescens, and the most important 
chlorophyll tissue during the most of the year in Parkinsonia and Zizyphus parryi.

12. The volume of the chlorophyll band for a unit stem has a value of 1 in Celtis, 4.1 in Koberlinia, 4.7 in Parkinsonia, and 5.7 in Prosopis. The least volume oceurs in evergreen forms; the greatest in plants which depend in part or entirely on it for photosynthesis.

13. The thickest chlorophyll band is in Parkinsonia, which is $246 \mu$ in a stem $4.9 \mathrm{~cm}$. in diameter. The thinnest band is in Celtis, which is $25 \mu$ in in a stem $1 \mathrm{~cm}$. in diameter.

14. Chlorophyll usually disappears carly from the woody portion of the stem, but in Parkinsonia it may be found in stems $1 \mathrm{~cm}$. in diameter.

15. When the chlorophyll band is palisade, the character of the palisade is very similar to that of the leaf of the same plant.

16. The following species were studied: Aster spinosus Benth., Baccharis cmoryi Gray, Celtis pallida Torr., Cereus giganteus Englm., Condalia spathulaca Gray, Covillca tridentata Vail, Ephedra antisyphilitica C. A. Meyer, Fouquieria splendens Englm., Franseria dumosa Gray, Krameria canescens Gray, Kuberlinia spinosa Zucc., Olneya tesota Gray, Parkinsonia aculeata L., Parkinsonia microphylla Torr., Parkinsonia torreyana Watson, Prosopis i'elutina Wooton, Salix nigra Marsh, Sambucus mevicana Pres1., Zizyphus parryi Torr. 


\section{The Induction, Development, and Heritability of Fasciations.}

BY

ALICE ADELAIDE KNOX. 




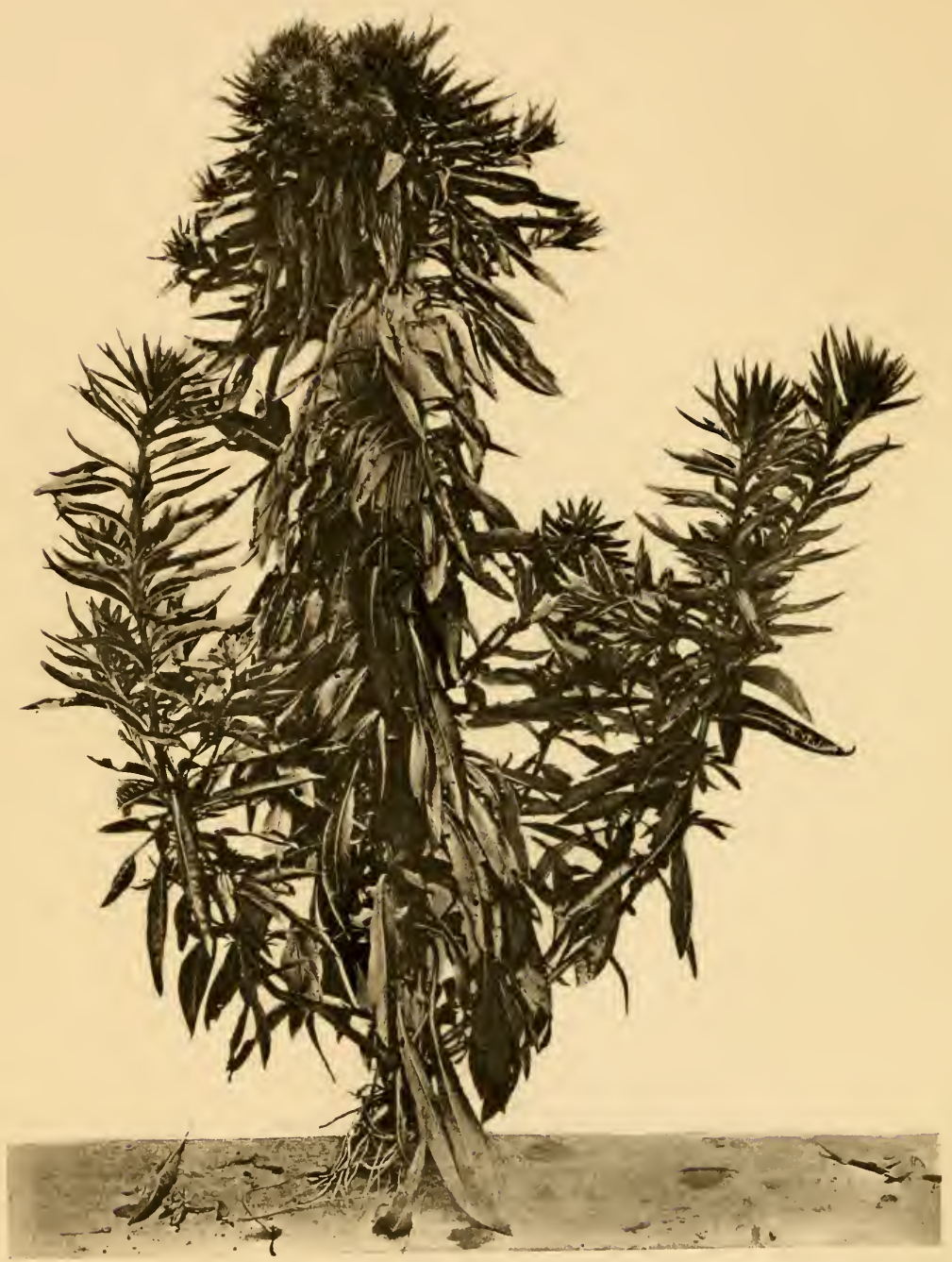

OENOTHERA PARVIFLORA. Fasciation of the main axis, with incipient fasciation of the side branches. 


\title{
THE INDUCTION, DEVELOPMENT, AND HERITABILITY OF FASCIATIONS.
}

\author{
By Alice Adelaide Knox.
}

The definition of fasciation given by the earlier writers inchudes plants with axes which, normally round or polygonal, have become flat, and which, wholly or in part, develop through a linear instead of a cone-shaped growing region. Such stems are commonly referred to as banded or ribbonshaped; they produce abnormal numbers of leaves and flowers; they possess an altered phyllotaxy; and they usually show bifurcations, or splittings, somewhere through their length. The last tendency is so marked that fasciation may be said to include two tendencies-one toward the enlargement and another toward the division of the axes affected.

Ring-fasciations have circular growing regions, and the upper part of the stem is shaped like a funnel with a cavity continually wider toward the top. The funnel commonly breaks on the side, and the stem finally becomes flat; for this reason they, too, come under the head of the banded forms. The various torsions of stems of this character described by Godron (4),* Masters (3), and others, seem to be caused by inequalities of growth resulting from injuries on the concave side. The fact that the curves may be caused by injury is referred to by Nestler (7) for Sambucius nigra and Sonchus palustris, and will not be especially noted in this paper. Plate I, and plate II, figs. 1 and 3 , give an adequate idea of the vertical development of fasciated axes. The material for the research presented was gathered from the venotheras of Dr. D. T. MacDougal's experimental ground at the New York Botanical Garden and from the plants of a waste field of $O$. biennis in Bedford Park, New York City. Many years ago Knight. (1) advocated enrichment of the soil for the culture of cockscombs, and de Vries also has repeatedly emphasized the necessity of plenty of fertilizer. The experimental garden provided the requisite conditions, but although fasciations were more abundant in the rich ground their prolific production on plants that grew wild in the sandy waste land illustrated the foree of de Vries's further conclusion (19) that the innate character of the plant is more important than the environmental factors, significant as he deems these to be.

The life-cycle of biennial primroses divides itself into. (a) the rosette stage, and $(b)$ the adult stage, when the flowering stalks develop and fruit. - The

*The figures in parenthesis refer to the bibliography, page 18 . 
study of fasciation is naturally grouped about these two periods. The character of the fasciated rosette, with broad, linear heart, giving rise to stems flattened from the base, has been made familiar by de Vries (11). In the cultures such rosettes reached a breadth of $3 \mathrm{~cm}$., and the stalk from one of them produced a vegetative line which eventually measured $38 \mathrm{~cm}$. (plate I). In other cases the first evidence of fasciation in the rosette is a bifureation of the growing region, and two tiny buds sometimes appear even between the cotyledons. The two types of rosettes are illustrated by plate Ir, fig. 4, and by text-fig. 1. The fasciation of the flowering stalks is far more

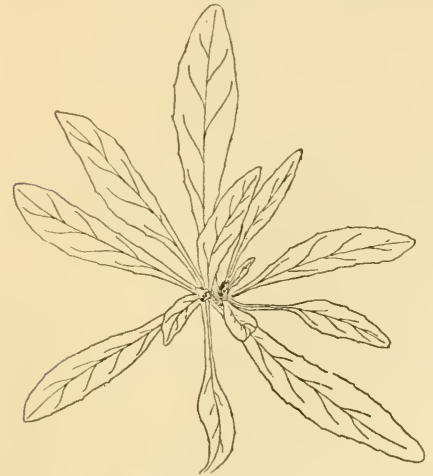

FIG. 1.-Raimannia odorata, bifurcated rosette. common than that of the rosette and furnishes the bulk of the material for observation, as well as for histological examination. Usually the rosettes have been plants to be kept for other experimental purposes, but the late branches may be cut at will. The flowering stems studied came mostly from two sets of plants-the wild O. biennis and the O. cruciata in the garden. There were many ringfasciations in the two groups, though these have been comparatively infrequently reported. The 0 . biennis, besides simple fasciations and ringfasciations, showed on many stems, associated with the banding, an indentation or groove, as represented in plate II, fig. 2, running up the upper half of the stem. The groove became wider and deeper as the stem flattened. Simple fasciations, ring-fasciations, and groove-fasciations occurred together, both on secondary and tertiary branches of plants of which the main axis had usually been stunted. Two descriptions may be taken as representative:

Plant 1.- The plant had 11 branches, which were all equal in importance, the main tip having been stunted early in its history. There was consequently no main branch, though $A$ was the largest secondary branch. The tip of $A$ was also stunted, and it had I 1 tertiary branches; of these, 7 were fasciated. The fasciations were split into two or more forks. Two of them showed round instead of flat divisions. In six cases below the bifurcations there were grooves. The secondary branch $B$ was also fasciated, with a flat tip. The flattening was in every case associated with old capsules, often with holes bored through.

Plant 2.- The plant had 9 branches. The branch $A$ had 6 secondary branches, all of which were fasciated. Two of them showed ring-fasciations, the others were flat, and two exhibited conspicuous grooves. Of the other branches, one showed a ring-fasciation and the others bifurcations and simple fasciations; 5 of them showed grooves so as to be recognizable. All of the main branches were fasciated. The total number of fasciations on the plant was 15 , 
There were also in the field three or four examples of the type in which the alteration of form dated from the rosette stage. These individuals were always stalwart plants and produced high, strong stems, of which the main axis was fasciated from the base.

In the (). cmiciata the fasciations were remarkably well formed. Some of them dated in their development from the rosette period, though usually the branches did not begin to flatten until $20 \mathrm{~cm}$. above the base. Many of them suddenly flattened from the time of the appearance on the stem of a hard protuberance, which was ustally cylindrical in shape and sometimes $2.5 \mathrm{~cm}$. in length, but often reduced to a small lump on the stem (plate III, figs. 1, 3, 4, 5). Ordinarily the stem fasciated from the point where the protuberance appeared and one or several of the forks were fasciated. If there were no forks the whole stem at once banded. There were also ringfasciations, and the three forms appeared on the same plant.

The description of a typical individual is as follows:

C. 6. 2.-The plant developed from a rusette which had been kept in a cold-frame from the previous fall ( $\left.190_{4}\right)$, and most of the branches showed by the early disarrangement of the phyllotaxy and by the shape of the stem that the fasciation had started during the rosette period. There were in all 10 branches, of which I was normal; 2 at the end of the second summer were small fasciated rosettes; 7 were repeatedly bifurcated, 3 of them eventually into 9 forks. Of these, 3 showed protuberances at the point of the first bifurcation. One stem had a heavy callus at its base, covering an old injury. In these 1905 plants there were no rings, but they appeared in 1906 on stock from the 1905 seed. The largest fasciation on the above plant measured $4.8 \mathrm{~cm}$. by $4 \mathrm{~mm}$. There was frequently a constriction or channel in the stem below, such as appears in the plant in plate II, fig. I, but not such as to be histologically akin to the grooves in the wild $O$. biennis.

In the cruciate forms of 1905 , on one plant 15 out of 16 branches were fasciated; on another, 10 out of 11 . For the microscopic study of this material there were to be examined simple flat fasciations, ring-fasciations, groove-fasciations, and the fasciations associated with the protuberances.

In normal structure stems of Onagraceze are much alike, and it is unnecessary to call attention to small differences. They possess a continuous bundle-ring, which is bicollateral in character. The medullary phloem is arranged in groups just within and following the line of the xylem. The outer phloem is in very small and inconspicuous groups amid a quantity of parenchyma cells. There is a stereome ring, and peripheral to this chlorenchyma several rows of collenchyma and the epidermis. The medullary rays are but 1 cell in width. The pith consists of large parenchyma cells, and there are many bundles of raphicles of calcium oxalate there and in the cortex.

There is a kind of latex system which consists of parenchyma cells which contain a brown secretion, most dense near the phloem, but conspicuous in pith, cortex, and epidermis. Sections stained in Delafield's hamatoxylin resulted in a bright purple in the cells about to crystallize, in brown or a greenish shade in the latex eells, and in a reddish purple 
or maroon color in the secretory cells of the parts exposed to injury. Simple fasciations when sectioned show the traditional structure of flat stems and do not vary from the normal exeept in outline.

Sections of ring-fasciations, as diagrammed in plate $\mathrm{IV}$, series 3 , follow closely the description of Nestler (8) for I'eronica longifolia in having, besides the primary bundle-ring, a second bundle-ring bordering the cavity of the funnel. This ring originates as a group of meristematic cells in the center of the medullary parenchyma. Gradually successive groups of meristem appear, arranged in a eircle, and these differentiate into typical bicollateral bundle-groups. The earliest group consists of several undifferentiated cells, which show their first trachea some sections above their initial appearance. The latter groups in their earliest stage consist of 2 cells side by side, a trachea and a nucleated prosenchymatic cell. The parenchyma cells in the center of the pith below the first signs of the ring are smaller than the peripheral cells and more crowded together. The phyllotaxy of the stem is already changed from the normal below this point, so that the loss of definite arrangement is seen to precede the formation of the meristems. The secondary bundle-groups gradually increase in size and merge together into the ring; there appears in the center of the pith a lysigenous cavity, which is the beginning of the hollow of the funnel, and further differentiation produces an internal epidermis, cortex, and stereome ring, in sequence the exact reverse of the primary arrangement in the periphery. At the apex the two bundle-rings merge into one. When the side of the funnel breaks, the two rings unite at the break and surround the elliptical pith of a simple flat fasciation. As there are leaves and flowers within as well as without the funnel, there are leaves and flowers on both sides of the banded stem.

The structure of the groove fasciation of the wild O. biennis, shown in plate IV, series 1, presents a case analogous to this. At an early stage of development a portion of the cambium is destroyed, the bundle-ring broken through, and the space is filled with parenchyma. The expansion and increase of the undisturbed cells results in the constriction $g$, which is the external sign of the groove. In the interstice in the ring a meristem develops in the parenchyma, succeeded by other meristems lateral to it. These differentiate into a line of bundle-groups which merge with each other and with the primary ring. During this process the stem flattens, although it is circular when the meristem appears. The flattening is a slow and at first imperceptible process, and the beginning of the alteration must be sought far below the point where it is visible to the naked eye. The distance of the open groove from the tip is 17 to $26 \mathrm{~cm}$. ; the stems are flat and broad 12 to $19 \mathrm{~cm}$. from the tip; the meristem begins from $2 \mathrm{to}$ $4 \mathrm{~cm}$. below the opening of the groove. The early stages of the process may be followed by a reference to plate $\mathrm{v}$, figs. 1 to 3 . The origin of the meristem 
is represented in fig. 1; a later stage in fig. 2 shows the character of the meristematic groups embedded in thick-walled parenchyma, and in fig. 3 the gradual differentiation into phloem and xylem is pictured. Intermediate between the ring and the groove types is found an example illustrated in plate IV, series 4, of what is elassed by Nestler (8) in $I$. longifolia as an "imperfect ring." In this the meristems arise in the pith, a ring of bundles develops there, and the ring passes over to one side until it tonches the primary bundle-ring, with which it then fuses. At this point the flattening of the stem first becomes marked. In one individual the lysigenous cavity, characteristic of the ring-fasciations, formed within the second bundle-ring and passed out into the cortex when the two bundle-rings merged. Stems with the protuberances on the plants of (). cruciata when sectioned (plate IV, series 2) reveal conditions similar to those of the two types preceding. The medullary parenchyma cells in the eenter of the stem become smaller and more closely crowded together. A meristem then arises in the pith and, after differentiating into a secondary bundle-ring, becomes part of the primary ring, as in the intermediate or ring-groove type. The composite ring then bulges out at the point of fusion, and a portion of it is cut off to form the protuberance. This cylindrical process (plate V, fig. 4) possesses a woody bundle-ring, but there is no apical meristem and, near the tip, primary trachea and sieve-tubes run irregularly across its axis (plate v, fig. 6). Above this are irregular, yellowish callus cells (plate $v$, fig. 5). In a very common variant of its structure, serial sections show, in the pith below the protuberance, a group of cells formed of trachea and sieve-tubes, which run transversely and in great confusion. As this group passes toward the periphery and touches the primary bundlering the regularity of arrangement is disturbed in the latter, and is only restored after the knob has been entirely eut off from the stem. In another variant the meristem does not appear below the protuberance, nor does the stem fasciate. In a case of this kind the cortex around the main stem was found to be eaten off by insects, the growing region injured, and the lower buds forced out. This is simple abortion of the main axis, with destruction of leaves and buds, which leaves the surface of the aborted stem in the form of a hard and smooth projection. The variations of these regions, of which there may be said to be almost as many as there are specimens, together with the variations of the rings and grooves, are all manifestations of the same principle. The early conditions of one are doubtless similar to the conditions of all, and for this reason special interest attaches itself to the young stages of any of them.

A young protuberance with accompanying fasciation was found in a stem of $O$. cruciata, illustrated in plate III, fig. 6, which was cut in September from one of three slow-growing plants which had elongated $20 \mathrm{~cm}$. from the rosette stage. The phyllotaxy was disturbed for $3 \mathrm{~cm}$., and the leaves 
abnormally crowded for $1.5 \mathrm{~cm}$. Transverse sections of a growing region revealed callus over the main tip, just above the pith. The procambial strands about the callus seemed unaffected by the injury to the apical meristem and were continuing thir activity. Longitudinal sections of a second plant (plate r, fig. 7) showed callus at the tip of the main axis in the former position of the apical cells. Beneath it trachece and sieve-tubes had differentiated and ran irregularly, many in a transverse direction, across the apex. A section of this stem is seen in plate $\mathrm{v}$, fig. 8, and shows the callus and the apical conditions. The slight depression under the callus is surrounded by a ring-shaped meristem (plate v, fig. 7 ). The tip has evidently been injured, the meristem has spread in a circular direction, and has become distributed as a ring. As enlargement takes place in the tip of the stem, its apex will project as a protuberance of greater or less development, showing transverse bundle-elements beneath a mass of callus. When unequal growth pushes the callus to one side the ring splits and the stem becomes flattened. The origin of the injury which induced callus formation is to be found in the surrounding plants. In 20 rosettes of $O$. cruciata next these individuals larvæe were feeding, and as the leaves of one of the three in question were freshly eaten, and as another contained a larva within the stem in the lower part, these insects were undoubtedly the agents which attacked the young tips.

The relation of certain insects to the œenotheras is known to be a constant one, and more than one genus is recognized as parasitic upon them. The forms found in Bedford Park and in the experimental grounds are species of Mompha, a tiny grayish moth with spotted wings. The eggs are laid in the leafy tips and, later, larvæe are abundant in the apices, the capsules, and the pith of stalwart plants. They are particularly common in rosettes toward the latter part of the summer, and as they develop many bind together the leaves to form a shelter and feed among the tender tissues in the winter and again in the very early summer. Most of them eat only young leaves and never reach the meristem; many devour and destroy the apical tissues; while still others irritate or injure them. They are found not only in the rosettes that come from seed, but in those which form in late summer at the ends of old branches to carry over a perennial growth. The fasciated rosettes of late summer frequently appear in pairs, and it is common to find callus and inhibition of growth between the two (plate v, fig. 9). The condition of the branch seems to indicate that the main axis has been destroyed and the side-buds injured as they were foreed out. Such branches commonly have circular meristems in the pith, surrounding spots of brown discoloration of the sort which develop about masses of dead cells.

A second kind of injury may arise through the ovipositors of the insects. In the pith of woody stems of $O$. cruciata, O. pariflora, and O. biennis, and in the capsules of $O$. grandiflora and other forms, are larve closely related to those in the rosettes. Those which undergo metamorphosis in the 

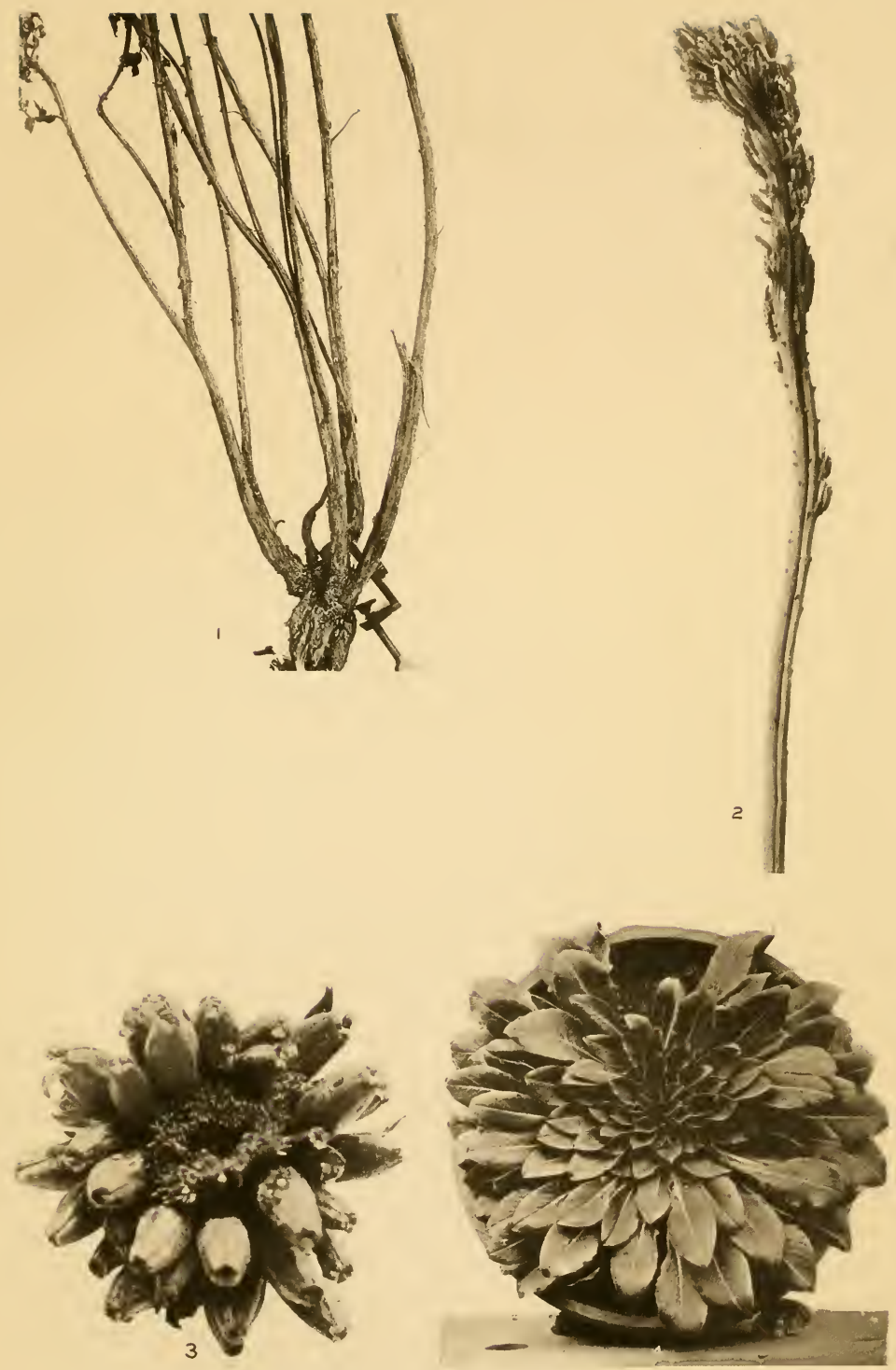

I. - OENOTHERA HYBRID. Fasciations developed from a bifurcated rosette.

2.-OENOTHERA BIENNIS. Grooved stem with fasciation above.

3.- OENOTHERA CRUCIATA. Ring fasciation.

4.- OENOTHERA BIENNIS. Fasciated rosette.

(See also text figure.) 

capsules of $O$. grandiflora are Mompha brevivitclla, known at one time as Laverna cenothercerorella, and in May and again in July the insects are constantly invading the tips. The slightest irregularity in the arrangement of the young leaves during or just preceding the flowering period, an appearance like that shown in plate III, fig. 2, or such as might result from some external mechanical interference, indicates that the tip when sectioned will prove to be fasciated or bifurcated. There is no sign externally of the fasciated outline in these tiny tips, merely reddish color, inequality of development, or a tiny aperture suggesting a callus. Microscopical examination proves ring-fasciations and protuberances to be abundant, and simple fasciations occasional. The development at this stage covers less than $5 \mathrm{~mm}$. of the stem, but is none the less perfect. Two such apices are diagrammed in plate $\mathrm{v}$, figs. 10 and 13. In many tips are found long, needlelike incisions, illustrated in plate $\mathrm{v}$, figs. 11, 12, and 13, as if made by an ovipositor. About these the cells have hypertrophied, and cylindrical meristems are forming. Throughout the stems at intervals are small areas surrounded by hypertrophies and meristematic conditions (plate v, fig. 15). These are akin morphologically to the meristems in the pith of the old rosettes, and are like those about the track of the larvæ in stems in which the pith is infested with the latter. All of them are readily recognizable because of the purplish intercellular secretions, seen in plate v, figs. 11, $12,14,15$, and the changes are those which customarily follow in the neighborhood of dead cells. Tips of this appearance collected July 27 , 1906, were bifureated, if not definitely fasciated; none of them were normal; and there were "stings"' of various sorts in them all.

The anatomical structure of rings and grooves and of the protuberances proves them to be variations of a single type, for the essential features of their development are the same. The protuberance varies so greatly in its structure and in its morphology that its simplest form is a mere callus associated with a few irregular bundle-elements projecting from the side of the stem (plate III, fig. 4 , and plate $\mathrm{v}$, fig. 10, $k$ ). It is easy to conceive cases in which the injury is so small as to be impossible of detection. Incisions in young meristems are quickly obliterated by the turgidity and growth of the surrounding cells (plate v, fig. 12), and it may be assumed that many fasciations are caused by injuries too delicate to follow in any but the initial stages. Only chance enables one to find such stages, and innumerable tips may be sectioned without avail. To a stimulus of this nature, obscure in its histological effects, the simple fasciations must owe their origin. They occur on the same plants with those more easily detected, and may themselves, when bifurcated, be recognized while comparatively young. Yet the stimulus is slow to produce the abnormal condition, and the irritating cause is concealed before the effect is seen. In a tip of O. biennis which contained an active larva, a group of very small parenchyma cells had differentiated in the pith. This is the condition that 
precedes a ring-fasciation, though as yet no ring-fasciation was apparent. In all wild $($ ) biennis the stems were infested with larve below the fasciations and the grooves full of callus, yet it was impossible to find intermediate conditions. A plant with a fresh larval trail up the side fasciated after a month of elongation from the rosette stage, but by the time the character of the tip was well determined the first effects were obsenred by the later growth. Unequal formation of wood on the two sides at the base of fasciated stems may be taken as an indication of local inhibition. Transrerse sections of the lower, round part of branches, which are flat above, ustrally reveal variations in the width of the woody ring. The difference may be slight or, in a few cases, as in plate $v$, fig. 16, very marked and accompanied by callus formation. In the groove-fasciations (plate IV, figs. 1b, 4b) the width of the primary wood where it adjoins the groove, at $x x$, is narrower than at $y^{\prime} y^{\prime}$. This is also found to be true in sectioning the rosettes cut in late summer from the old stems (plate v, fig. 9).

What has been said applies to plants out of doors. It seemed probable that a different state of things would hold in the greenhouse. Yet the fasciated rosettes in the greenhouse have in the stems circular meristems about brownish discolorations and a significant feature of their development is one-sidedness of growth and a forcing out of the axillary branches. Rosettes of $O$. cruciata planted June 16, 1906, and kept in the greenhouse during the summer, were subject to such conditions in the pith. These, like the rosettes of O. parviflora of 1905-1906, showed rough places on the petioles and midribs of the leaves, incurling of some of the leaves in the growing tip, and ruffling of the margins. The 0 . pariflora planted in the summer of 1905 , in December, showed larger and longer leaves on one side than on the other. There was then no sign of linear growth, but in April they began to fasciate, and in May all four plants were fasciated. Frequently the rosettes tip 11 , owing to the premature development of a lateral branch (plate II, fig. 4), so that one side is higher than the other. This looks as if there were inhibition of growth on the concave surface. The result of further growth is often a complete torsion of the faseiated main axis with fasciation also in the side branches. In studying fasciation, species with compact symmetrical rosettes are much to be preferred. $O$. grandiflora is among the impracticable forms, for the side branches normally come ont very early. A double rosette of Raimamnia odorata, a near relative of the oenotheras, the plant illustrated in text fig. 1 and in plate $\mathrm{V}$, fig. 17 , when sectioned was found to have been injured below the bifurcation, and at this point $(x)$ there was inhibition in the formation of wood. Only the bifureated fasciations can be detected at the start, and these are of comparatively rare oceurrence. It is evident, however, that the rosettes under cover are not exempt from outside injury, and insects may readily enter the greenhouse through the open ventilators, besides the many which habitually live there. 
The extensive experiments of de Vries, which have led him to consider certain fasciations hereditary to some extent, made it desirable to test its inheritability in these cultures. Pure seed was saved in 1905 from fasciated plants of $O$. cruciata, and of (). muricata from Kansas. The O. cruciata came from material originally collected by Mr. S. H. Burnham at Lake George, New York, in 1903. Of his 15 plants, 7 afterward fasciated in the main stem, and 3 of them when grown produced "curious elbow-shaped structures" on the stems. These protuberances were variants of those which appeared in the later eultures. Pure seed from the fasciated individuals was sown in 1904, and 5 plants saved out. These fasciated in the main and side branches, and from them pure seed was sown in February, 1906, and 57 plants saved out. In September, 1906, counting the main stems only, 5 of these were stunted and 2 normal; there were 30 fasciations and bifurcations associated with protuberances, 12 simple bandings, 3 unflattened bifureations, and 5 ring-fasciations. In the normal stock plants there were in one group of 3 individuals, 1 ring and 2 bandings; in another of 4 plants, 2 protuberances, 1 bifurcation, and 1 simple fasciation; a third, of 4 individuals, contained some fasciated side-branches on each plant. The seed of the O. "muricata" was sent by Mr. H. F. Roberts from Manhattan, Kansas, in 1904. The first sowing was made in November, 1904. Although distributed as " muricata,'”. it proved to be an elementary species removed from the muricata type. Two out of the three plants saved fasciated in the rosette stage and bloomed in the summer of 1905. From one of these pure seed was saved and sown in February, 1906. In September, 1906, out of 43 plants, 26 individuals were fasciated, 3 stunted, 2 bifurcated, and 12 apparently normal. Counting only the flattened tips, 60 per cent were fasciated. In the 3 control plants from unfasciated stock, 2 were fasciated and 1 stunted. The control in each case fasciated as readily as did the fasciation cultures.

Aside from the series which were run as special tests there were numerous examples of fasciation in Dr. MacDougal's general collection. In 1905 fasciation was found in 55 individuals, including $($. lamarckiana, ( ). muricata, O.biennis, O. oakesiana, O.strigosa, O.gigas, O. nanella, O. grandiflora, $O$. lamarckiana $\times O$. biennis, and $O$. cruciata, besides many forms of doubtful identity. In 1906 it appeared in 86 individuals, representing 34 different cultures and a correspondingly wide range of species. Next to O. cruciata, O. pariflora fasciated most abundantly. The plants were in four different lots from Maine and in one lot from Madrid. All of the individuals fasciated in 50 per cent of their branches. Of the (). grandiflora from Alabama, 14 plants were fasciated. In the O. ammophila all 5 plants were fasciated in main and side branches. In one group of 4 plants of O. lamarckiana, from a parent raised after a succession of pure cultures from seed originally sent from de Vries in 1901, all 4 plants were fasciated in the main stems. The anomaly can scarcely be considered hereditary in 
all of these forms, gathered in from all over the world, nor can it be regarded as the sporadic appearance of latent characters. The fact that in many series from normal races, 100 per cent of the individuals planted out fasciated, though no selection was exereised in saving the rosettes from the large numbers of seedlings originally planted, strengthens the inference that its development is due to local causes. One is led to conclucle that there have been prevalent in the garden and in this region during the summers of 1905 and 1906 swarms of insects whose attacks upon the growing tips were particularly insidious and stimulative without being at the same time destructive. It happened, too, that several species of the primroses were markedly susceptible to the injuries, and that the conditions of light and nutriment were favorable to vigorous development. Given similar conditions of culture, the factors invalved in the production of the fasciations are the specific mode of attack of such insects, the character of the plant, and the rapidity of development; the second of the three is the most important, as it is true that in two adjacent groups of $O$. biennis, one will fasciate and the other will not. It is also true that the form of the fasciation varies with the group affected. Thus $O$. "muricata" from Kansas, $O$. parviftora, $O$. ammophila, and $O$. grandiflora developed simple-banded fasciations, while rings and protuberances appeared on the O.cruciata and grooves on the wild $O$. biennis. The $O$. cruciata from the Lake George stock differed from the $O$. cruciata varia (?) from Hamburg, which may be what de V'ries calls a poor race. Of this $O$.cruciata zaria (?) 40 plants sown at the same time with the Maine cultures, of which the rosettes were bifurcated, failed to show fasciation either in the rosettes or branches.

This group of plants flowered much earlier than the others, which calls attention to the importance of the late development of the individual. Most of the fasciations date from the period just preceding the opening of the flowers in July, and they flatten among masses of fruits, or at a point where the stung flowers have fallen off and left the stem bare. From this time the eggs of the momphas are laid, the larvæ develop, and new swarms of imagos begin to emerge toward the end of the summer, at once proceeding to sting new tips. Those apices which have passed the period of greatest vigor gradually dwindle away and die, but leafy axes, leafy rosettes, stems ready to flower through September, all soft tissues in a thriving condition, then fasciate in greater abundance proportionately than earlier in the season, for their limited number makes it more certain that they will be attacked by the recent.invasion of the new swarm. In the rosette stage the rate of growth is also important. It is seldom that the insect reaches the apical meristem of a quick-growing plant, for the rapid formation of new leares supplies sufficient food for the larva, and the formative region remains untouched. Sections of numbers of young rosettes containing larvæ easily prove that the inseet ordinarily feeds above the apex or at its side. Though plants are often unaffected by the parasites, doubtless swarms occasionally 


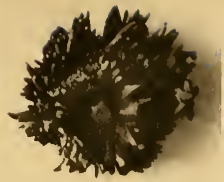

I
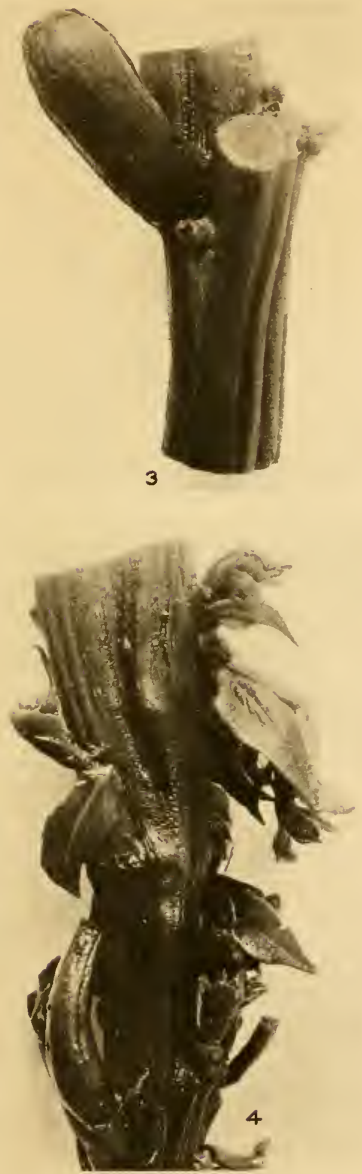
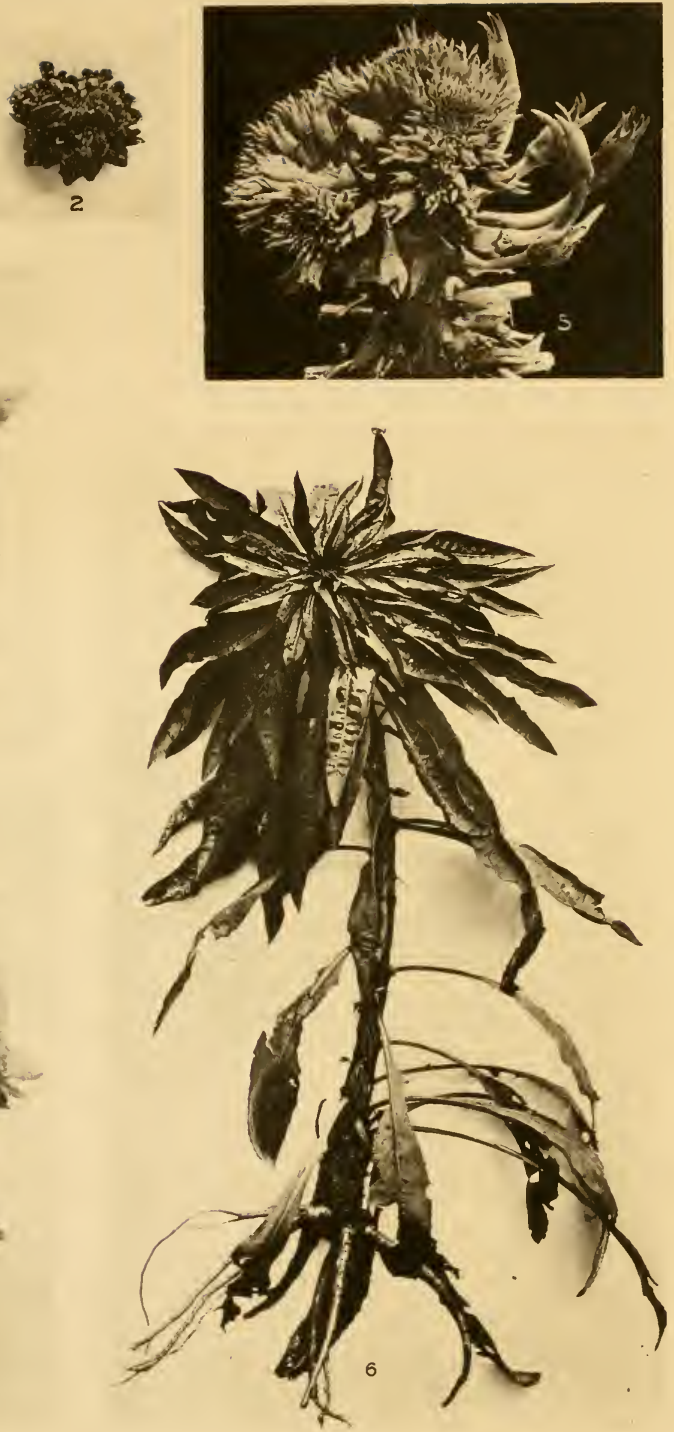

OENOTHERA CRUCIATA. I. Young protuberance. 2. "Stung tip." 3. OId protuberance and bifurcation with one fasciated branch. 4. Protuberances associated with the flattening of the stem. 5. Protuberance surrounded by fasciations. 6. Early stage in the formation of a protuberance. 

develop whose mouth-parts are sharper than those of their fellows, or whose habit it is to bore deep for the youngest and most tender food. In the same way there are swarms of imagos which have longer ovipositors, or which show a preference for the center of the apex rather than the axils of the embryonic flowers. If the character of the attacks of the insects varies with the character of the insect swarm, this should account for the widespread appearance of fasciation over one restricted locality, while in adjacent areas, beyond but insignificant barriers, no fasciated plants are found.

The "curious"' habit of fasciated stems in that those of annuals are at first round and later flatten, while those of biennials originate large and flat and stay so, has been noted by de Vries (11). In the primroses under observation this seems to be accounted for by the state of development at the time of the sting of the insect. In the cultures of $O$. pariflora rosettes planted in the summer of 1905, and kept over, fasciated during the winter; those sown in February elongated quickly after being placed out and faseiated in the upper parts of the branches. Two plants of the February sowing, which grew more slowly than the others, were fasciated rosettes in September. In general, plants or branches which were in the rosette stage in July and August, or at the time when the insects were laying their eggs and the larvæe were hatching, fasciated as rosettes and produced flat stems the following season. Plants in the flowering state during the same period fasciated in the upper part of the stems. Plants elongating from the rosette stage in September fasciated comparatively low down on the stem as in plate III, fig. 6. Any plant, moreover, may fasciate in its rosette stage the first season, and in the upper part of its side branches the second season. To secure the most striking results in New York, seed should be planted in April or May and allowed to remain out of doors in the rosette stage through the summer. Plants from seed sown in February begin to elongate too early to show linear growth long before the flowering tips are ripe. So many of the wild plants are aborted in the main axis that one may assume that the tip is eaten off by larva soon after the plant elongates from the rosette stage. Among the wild plants there were many larva in the field in June in the young shoots. The side-branches are doubtless injured as they are forced out, for the callus in the grooves of some of the branches and in the lower parts of the cavity of the rings in others indicates early effects of injury in these secondary branches.

The conditions of eulture, as has been already stated, were favorable to the vigorous growth of the garden plants. Individuals were from 2 to 4 feet apart and were well-fertilized and watered. The interesting experiments of de Vries and of Hus (22) at the Missouri Botanical Garden suggest that if some of the unfasciated plants had been subjected to different conditions they too might have fasciated. It is possible, also, that if the plants had been planted in April instead of in February the result might have been different. The environment must, however, be suited to the 
individual needs, for seed from the fasciated wild O. biennis of 1905 , in which the tendency toward fasciation was so marked, when sown in the garden in 1906 produced only one fasciation. The plants of this group flowered very early, however, and the time of sowing may have been as important a factor as the change of environment, or even more so.

That fasciation can be produced by mechanical injury has been known for many years, and Sachs (6) and Goebel (16) both treat of the old experiment where, by eutting off the epicotyl of certain germinating secdlings, the side-branches forced out are flattened. Phaseolus multiflorus is most commonly used, while de Vries employed Agrostemna githago (19). Nasturtiums also respond readily, and as high as 60 per cent of fasciated individuals was obtained in one water-culture. The injury must occur just after germination, and this has led to the theory that the anomaly is caused by overplus of nutrition rushing to undeveloped centers of growth (16). The effects in the seedling are not lasting, for the flattened branches soon revert to the normal shape. It is possible that the remoteness of the stimulus from the meristems affected may have to do with this. In the wnotheras the injury is to the initial meristem itself, and is of a nature so delicate that no relatively coarse instrument can duplicate it artificially. Repeated attempts were made to induce fasciation in the primroses with incisions by fine sterilized needles, but the needles either destroyed the apex altogether, in which case the side-branch did not fasciate, or failed to reach it at a11. Any incisions that could be made were so destructive compared with those of the sort represented in plate $\mathrm{v}$, fig. 13, that the attempt was finally abandoned altogether. It is interesting to note, in support of the theory of the influence of nutrition, that the effects in the onotheras come during the rosette stage and just before flowering, the times when the elaborated food supply is most abundantly centered at the growing apex.

The discussion of the nature of fasciation has centered about the morphology of the enlarged axis, whether it is the enlargement of a single growing point, as exemplified by Mouquin-Tandon (2), or whether it is the adnation of several axes, as explained by Masters (3). After a careful histological examination of fasciated growing tips of certain Phanerogams and Cryptogams, Nestler ( 7 ) found no evidence in favor of congenital adhesion. The growing line gave no sign of complexes of growing points, but represented an enlarged area of meristematic cells. In the onotheras there has never been any evidence in favor of the concrescence theory. In one single bifurcation for a short distance the epidermis elosed around two separate axes, but this was accidental grafting of two separate tips. The phenomena of fasciation are phenomena of multiplication, of increase in numbers of stems and leaves, and of the number of cells which enter into their composition. Once the physiological balance of the growing cells is changed and the chemical equilibrium altered by the peculiar stimulus of the mechanical contact, the tendency to multiply develops, and frequently 
continues to the end of the life of the plant. If there were fusion of a definite number of growing regions there would seem to be a definite limit to the increase in the size of the stem and the number of the leaves. Concresence may, and frequently does, occur as a consequence of the bifurcation which is so intimately associated with it, but is an accidental rather than an essential factor, and suceeds rather than precedes the division of the axis. As to the reason for this curious alteration of form in these fasciated stems, one can speak only theoretically. It may be that the banded fasciations arise from lateral injuries in which the inhibition causes the meristem to stretch from the point of attack. This might seem to be illustrated in the case of the rosettes of one-sided development and of the injured stems plate $\mathrm{v}$, figs. 9 and 16 . In the ring-fasciations the injury may be to the tip of the growing meristem, and the stresses thereafter distributed in a circular fashion.

Bifurcations are often caused mechanically by the stresses of old and broad fasciations, where the unequal growth and the consequent torsions strain the large growing region into segments through virtue of its unwicldy size. It is to be expected that a fasciation such as that in plate I would soon divide in this way if allowed to grow to maturity. The splitting of the axes may be more frequently mechanical than superficially appears to be the case. We must suppose that in its early stages it is often due to the stresses of vigorous growth in an abnormally large tip. The tensions which are parallel with the vegetative line are greater than those which cross it. A slight disturbance of external conditions, and so of the growth, upsets the equilibrium, and the tension is broken. It must be remembered, as Nestler has shown (7), that the apex is not level, but undulate, and it may be supposed to be constantly changing. Certain delicate adjustments of the stresses may keep the equilibrium until alteration in the rate of growth, due to inequalities in nutrition over so extended an area, upset the balance and free a portion of the axis. In the smaller segments the stresses are not so great ; consequently there is increasing tendency toward normal growth, and the smallest bifurcations usually in the end completely reverts to it. Bifurcations sometimes, both in ring-shaped and in flat fasciations, are caused by injury, but in many cases such an origin can not be assigned to them.

Though the development of fasciation has often been referred to external stimuli, there is but one direct reference to its connection with insects. Molliard (15) in 1900 found the larva of a coleoptera within the fasciated stems of Raphanus raphanistrum and of Picris hieracioides, just below the banded portions of the axis. He suggested that the parasite modified the structure of the vegetative point and changed the mass of the initial meristem from axial symmetry to the symmetry of a line.

Peyritsch (5), in his interesting experiments on the production of abnormalities through inoculation with Phytopus, enumerates, among the aberrant 
forms found in the Valerianacer, "fasciation of side-branches of a slight degree and disarrangement of phyllotaxy." He later says: "All the foregoing anomalies are phenomena of infection and owe their form to the stimulus of a parasite." Although these experiments were never published in detail, and emphasis was laid on phenomena other than those of fasciation, the hypothesis that fasciation was due to infection was evidently in the author's mind. Had he lived longer he might have taken up the subject more specifically and demonstrated it in relation to the Valerianacex. He concludes his article with the following sentence: "I am convinced that many instances which have hitherto been explained as spontaneous variations owe their origin to the activity of insects, although a Phytopus need not always be the stimulus."

The analogy of the artificial production of fasciation leads one to infer that the insect is but very indirectly the cause, and that the physiology is the physiology of traumatic after-effects. The nature of the changes in the chemical and physical conditions of cells after wounding is as yet but imperfectly understood, and the enormous hyperplasies resulting from the mechanical irritation of foreign substances, especially those associated with the parasitism of insects, are among the most interesting of unexplained physiological phenomena.

The following points are to be emphasized in summing up the foregoing statements:

(1) In the onotheras the histology of the early stages of development of fasciated stems is varied. Many different forms are found related anatomically to each other and to ring-fasciations. All may occur on the same plant, and the differences between them are morphological, not physiological.

(2) The fasciations arise through the agency of injuries inflicted upon the growing regions by insects. Bifurcations without definite flattening. develop through the same set of stimuli.

(3) The injuries must be inflicted upon the initial meristem, and can ordinarily be detected only microscopically, and at the earliest period of the ensuing growth. In such cases their course is almost immediately obscured or obliterated by the development of the surrounding cells.

(4) Injuries may result in the abortion of the whole or part of an axis, or in the formation of small processes on the stem. These malformations are described as "protuberances," and their development is almost invariably associated with fasciation or bifurcation, or both.

(5) Plants infected early in the rosette stage fasciate as rosettes; those infected after the stems have begun to elongate are fasciated only in the upper parts of the branches.

(6) To secure the greatest number of fasciations, the plants should be given the best conditions for their individual development, and the seed should be planted so that the period of greatest vigor may correspond with the time when they are most sure of infection. 
(7) The morphology of the fasciated stem is the enlargement of a single growing point. There is no evidence of fusion in the growing region.

(8) When tested in pure cultures, the progeny of fasciated individuals show no greater tendency to fasciation than the progeny of normal plants. The effects of the stimuli causing these malformations in the evening-primrose are therefore to be taken as in no wise heritable.

In conclusion, the writer wishes to express her appreciation of the assistance and of the many courtesies extended to her by Dr. D. T. MacDougal, Dr. H. M. Richards, and by the director and the members of the staff of the New York Botanical Garden. The work was begun under the auspices of the garden and continued under those of the Carnegie Institution of Washington.

\section{LITERATURE CITED.}

I. KNight. On the cultivation of the cockscomb. Trans. Hort. Soc. of London, $4: 321,1820$.

2. Mouquin-Tandon, A. Éléments de tératologie végétale. Paris, 184 r.

3. Masters, M. T. Vegetable teratology. London, 1869.

4. Godron. Mélanges tératologiques. Mém. de la Soc. nat. des sc. nat. de Cherbourg, $16: 1871-72$.

5. Peyritsch, J. Über künstliche Erzeugung von gefüllten Bliithen und anderen Bildungsabweichungen. Sitzber. d. k. Akad. d. Wiss. in Wien, math.-naturw., Cl, $97: 597,1888$.

6. SACHS, J. Gesammelte Abhandlungen über Pflanzen-Physiologie, 1 : 597, 1892 .

7. Nestler, A. Untersuchungen iiber Fasciationen. Oesterr. bot. Zeitschr., $44: 3+3$,

1894.
8. Nestler, A. Über ring fasciation. Sitzber. d. k. Akad. d. wiss. Wien, math.naturw. Cl., $103: 153,1894$.

9. De VRIES, H. Over de Erfelijkheid der Fasciatiën. Bot. Jaarboek Dodonaea, 6: 72,1894 .

10. Ramaley, F. On the stem anatomy of certain Onagracee. Minn. Bot. Studies, 1 : 674, i 896 .

II. DE VRIES, H. Sur la culture des fasciations des espèces annuelles et biannuelles. Rev. gén. de bot., 11 : 1 36, 1899.

12. DE VRIES, H. Sur la culture des monstruosités. Comptes Rendus, Paris, 128: 125 , 1899 .

13. DE VR IES, H. Über die Abhängigkeit der Fasciation vom Alter bei zweijähriger Pflanzen. Bot. Centralblatt, 77:289, 1899

14. Lamarlière, G. DE. Sur la production expérimentale des tiges et d'inflorescences fasciées. Comptes Rendus, Paris, 128:1601, 1899.

15. Molliard, M. Cas de virescence et de fasciation d'origine parisitaire. Rev. gén. de bot., $12: 323$, 1900.

16. Goebel, K. Organography of plants. Part I. Oxford, Igoo.

17. Renaudet, G. Contribution à l'étude de la tératologie végétale de la fasciation herbacée et ligneuse. Thèse, Poitiers, I901.

18. Conard, H. S. Fasciation in the sweet potato. Univ. of Penn., Bot. Lab. Contrib., 2:205, 1901 .

19. DE VRIES, H. Die Mutations-Theorie. Leipzig, 1901.

20. DE VRIES, H. Species and varieties. Chicago, 1905.

21. Bionget, F. H. Fasciation in field peas. Plant World, 8: 170, 1905.

22. Hus, H. Fasciation in Oxalis crenata and experimental production of fasciation. Rept. Missouri Bot. Gard., 17: 147, 1906.

23. Puglisi, M. Contributo alla teratologia vegetale. 1. Fasciazione di Vescaria reticula, di Bunias orientalis. Ann. di botanica, 4:367, 1906. 
Description of Plate IV.

Semi-diagrammatic transverse sections of stems; size reduced to two-scvenths of given magnifications.

SERIES 1. O. biennis. Successive stages in the development of a groove-fasciation Medullary parenchyma, $m p$; region of cambium, $c$; region of outer phloem and stereome ring, $p h_{1}$; region of the inner phloem, $p h_{2} ; x y l e m, x y$; cortex,$c x$; epidermis, $е p$. $\times 44$.

a. Initial appearance of meristem, $p p$.

$b$. Appearance of supplementary meristems, $m_{1}, m_{2}$; position of groove, $g$; thickwalled parenchyma surrounding meristems, $p p$.

$c$. Differentiation of secondary bundles, $b_{1}, b_{2}, b_{3}$, etc.; callus, $c l$.

d. Gradual enlargement and increase of secondary bundles; region of outer phloem and of stereome ring, $p h_{3}$; region of inner phloem, $p h_{4} ;$ xylem, $x y_{2}$; cambium, $c_{2}$.

e. Union of secondary bundles with primary ring.

$f$. Last stage before complete fusion with primary ring.

SERIES 2. O.cruciata. Development of a fasciation associated with a cylindrical protuberance. Lettering as before. $\times$ is.

a. Initial appearance of meristem, $m$.

$b$. Differentiation of secondary bundle-ring, $b_{2}$, in the pith.

$c$. Connection of secondary bundle-ring with the primary ring.

d. Fusion of the same.

c. Beginning of formation of protuberance at $k$.

$f$. Protuberance cut off, $k$.

SERIES 3. O.biennis. Development of ring-fasciation. $\times 25$.

a. Appearance of a single meristem, $m$.

$b$. Development of supplementary meristems, $m_{1}, m_{2}, m_{3}$, etc.

c. Differentiation of meristems into ring of secondary bundle-groups, $b_{1}, b_{2}, b_{3}$, etc.

d. Appearance of lysigenous cavity, $c a$.

$\iota$. Gradual fusion of secondary bundle-groups. Inner epidermis, $e p_{2}$; inner cortex, $c x_{2}$; outer phloem of secondary ring, $p h_{3}$; inner phloem of secondary ring, $p h_{4}$; xvlem, $x y_{2}$; pith, $p t$.

$f$. Break in side of ring, making a flat fasciation.

SERIES 4. O.biennis. Four stages of the development of a specimen intermediate between Series 1 and 3 . $4 a$ corresponds with $3 c$. The secondary bundle-ring arises in the middle and passes to the side, where it fuses with the primary ring. $\times 20$. 

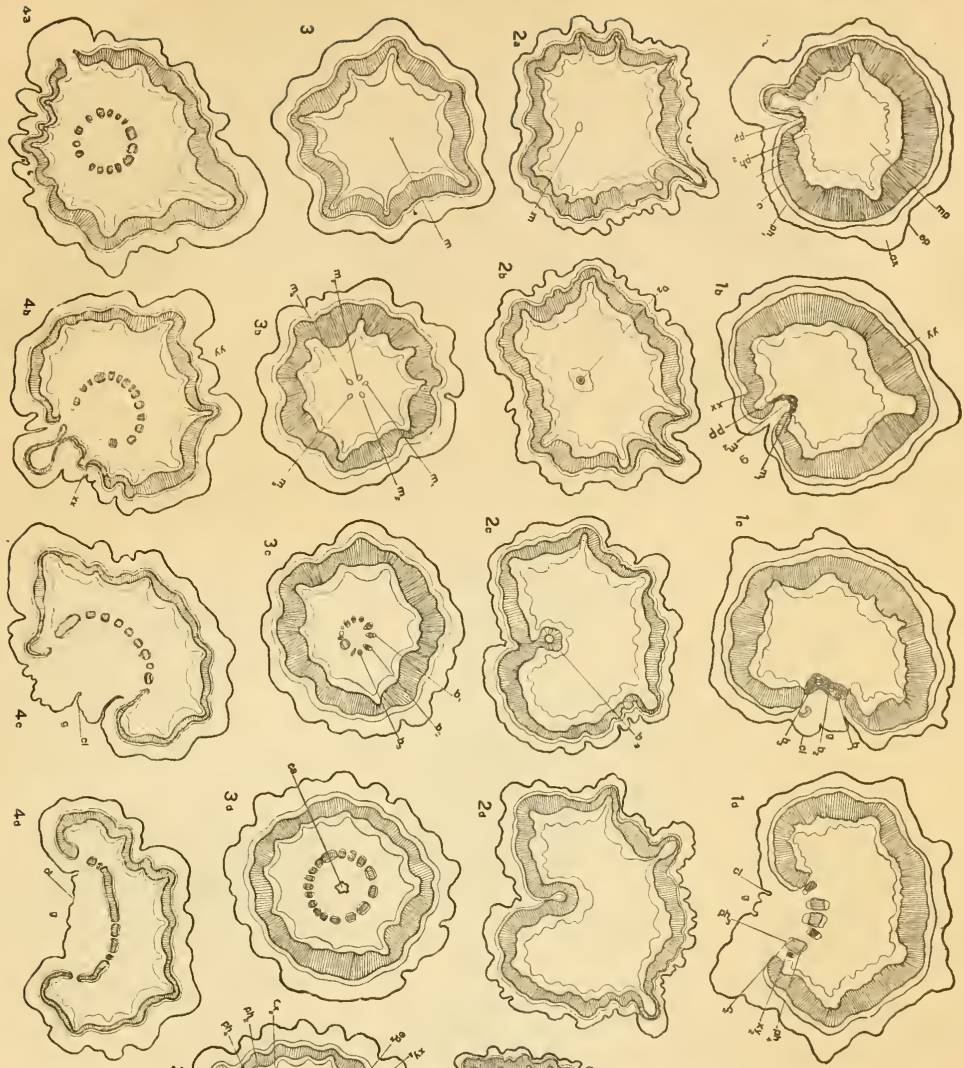

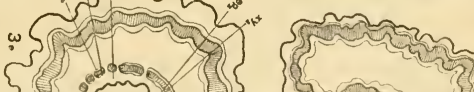
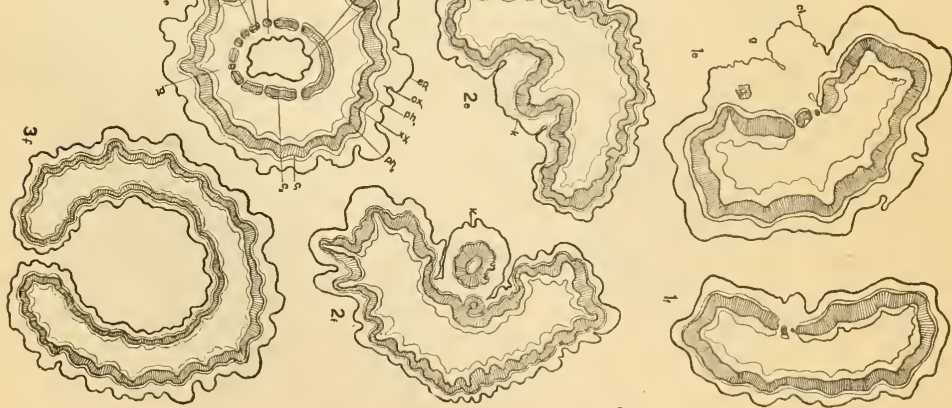


\section{Description of Plate V.}

[I rawn with an Abbé camera lueida and reduced to one-third of given magnifications.]

FIGS 1, 2, 3. Transverse sections of stems of O. biennis. Successive stages in the early development of a groove-fasciation. Meristem, $m$; thick-walled parenchyma, $p p$; medullary parenchyma, $m p$; cambium, $c$; outer phloem of primary bundle ring, $p h_{1}$; inner phloen of same ring, $p h_{2}$. Fig. I shows the lowest section of the meristem (plate $1 \mathrm{v}$, fig. $1 a$ ). The dark shading in the meristem indicates intercellular secretions. At $x$ the cambium has been destroyed. $\times 430$.

FIG. 2. Drawing of meristems in plate $\mathrm{I}$, fig. $\mathrm{I} b$. Two meristems $\left(m_{1}, m_{2}\right)$ appear in the break in the ring. $\times 430$.

FIG. 3. Drawing of two groups of secondary bundles, showing first differentiation of vessels. Secondary burdle-groups, $b_{1}, b_{2}$. $\times 560$.

F1G. 4. O. cruciata. Diagram of longitudinal section of a cylindrical protuberance. Bundle-ring, $b$; callus, $c l$; cortex, $c x$. $\times 25$.

FIG. 5. O.cruciata The same as fig. + . Group of callus cells from the apex. $\times 360$.

Fig. 6. O.cruciata. The same as figs. 4 and 5. Drawing of portion of apex of bundlering opposite point marked $z$ in fig. 4. Spiral ducts run transversely across the tip.

FIG. 7. O.cruciata. Diagram of longitudinal section of apex of plant shown in fig. 8 . Sections of vegetative circle, $v c$; callus, $c l$; primary bundle ring, $b . \quad \times 18 \frac{1}{4}$.

FIG. 8. O.cruciata. Longitudinal section of apex of fig. 7 at $\mathrm{cl}$. Callus, $\mathrm{cl}$; protophloem, $p h_{1}, p h_{2}$; proto-xylem showing spiral ducts, $x y$. This is an early stage in the formation of a protuberance. $\times 360$.

Fig. 9. O. cruciata. Diagram of cross-section of base of fasciated rosette which shows traces of injury. The oval shape of the pith shows the beginning of the flattening. Phellogen, $p g$; bark, $b k$; meristems in pith, $m m$; callus at point of inhibition of growth, $\mathrm{cl}$. $\times 8$.

FIG. 10. O.cruciata. Diagram of longitudinal section of bifurcated tip, showing position of callus, $c l$. At $q$ the bundle-elements run irregularly in a confused tangle. $K$ is a small protuberance. $\times 52$.

FIG. 11. O. cruciata. Drawing of longitudinal section of apex similar to fig. 13. An incision surrounded by hypertrophy and meristematic divisions. The contents of the cavity are stained reddish purple. $\times 560$.

FIG. I2. O. cruciata. The same as fig. Ir. Cells in pith surrounding the lower end of incision. The blackened edges indicate purplish discoloration between the cells. The cells lypertrophy and close in around the incision without dividing. $\times 480$.

FIG. 13. O.cruciata. Diagrammatic longitudinal section of an injured tip similar to the one pictured in figs. 11 and 12 . The apex seems to be slightly fasciated, and the stem is bifurcated. $i$, injury. $\times 25$.

Fig. 14. O. cruciata. Transverse section of early stage of ring-fasciation. The intercellular conditions indicate that it has been injured. C $f$. fig. I2. $m$, two cells of the meristem. $\times 560$.

Fig. 15. O. cruciata. Transverse sections of ring-fasciation in fig. 14 at a more advanced stage. Secondary bundle-ring, $b_{2}$, In the center of the pith is a cavity surrounded by hypertrophied cells and meristematic divisions. This is not the beginning of the lysigenous cavity of the ring, which occurs some sections above. $\times 430$.

FIG. I6. Transverse section of flowering stem just below the point of fasciation, showing inhibition in the formation of wood at $x x . \times 25$.

Fig. 17. Raimannia odorata. Cross-section of young bifuricated rosette, showing injury to cortex and inhibition in the development of the bundle-ring at $x x . \times 92$. 

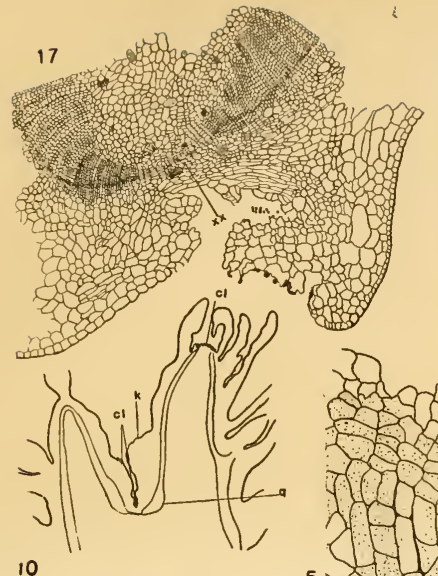

1)
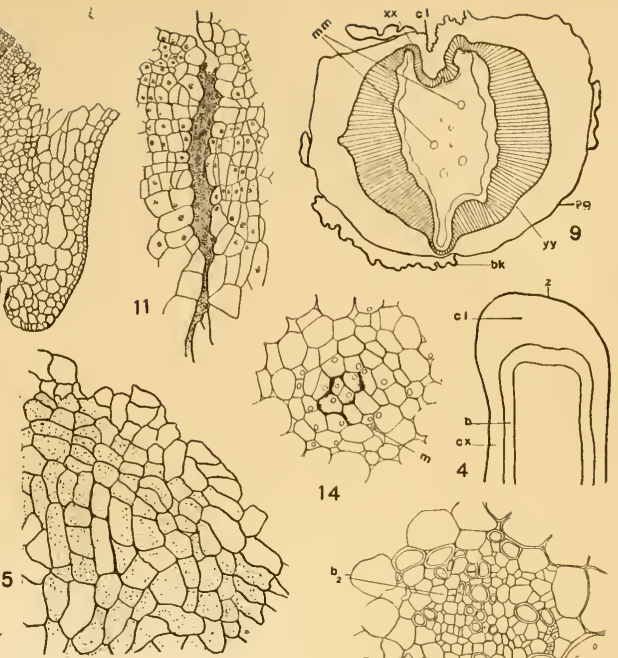

14
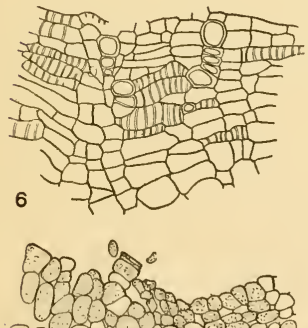
ano 000 ios
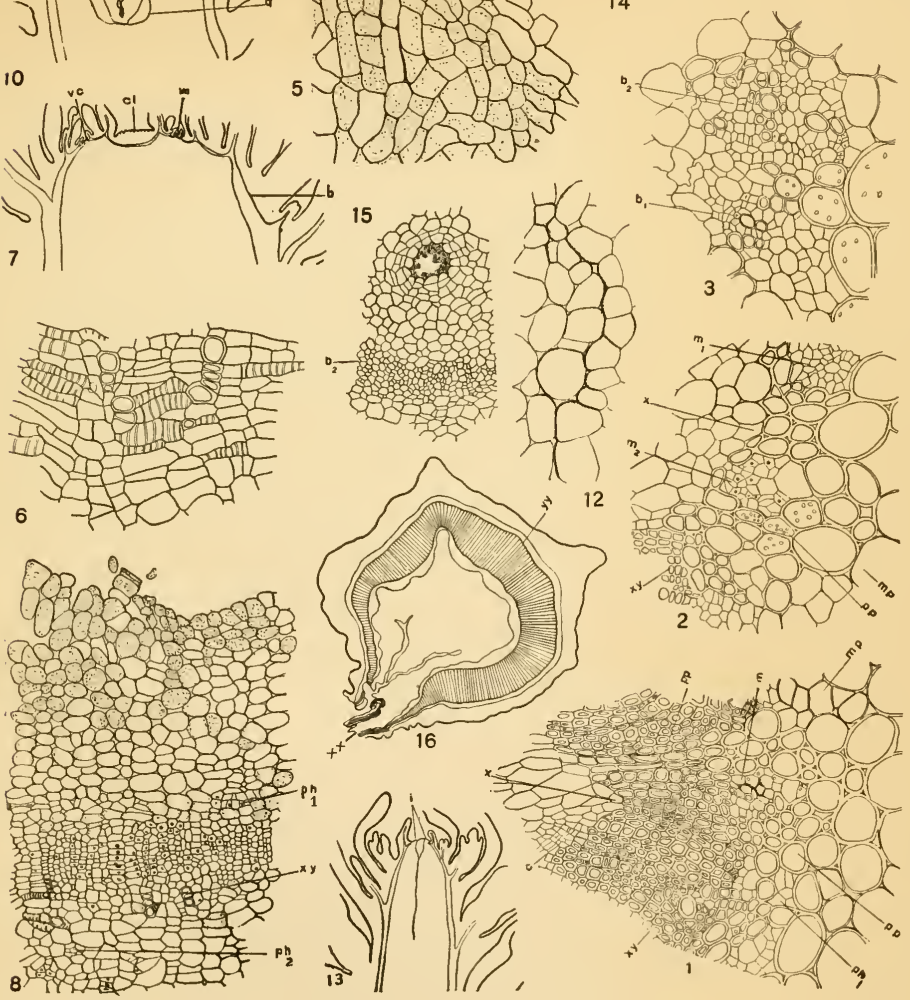



is
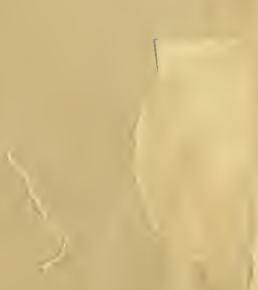
North Carolina State University Libraries QK882 .C3

INDUCTON DEVELOPMENT AND HERITABILITY OF FAS

|||||| || | || || || || || || || || || ||

S02778225 । 